Purdue University

Purdue e-Pubs

Purdue CIBER Working Papers

Krannert Graduate School of Management

1-1-1999

\title{
The Effect of National Culture on Partner Buyouts in Cross-Border Biotechnology Alliances
}

Timothy B. Folta

Purdue University

Walter J. Ferrier

University of Kentucky

Follow this and additional works at: http:// docs.lib.purdue.edu/ciberwp

Folta, Timothy B. and Ferrier, Walter J., "The Effect of National Culture on Partner Buyouts in Cross-Border Biotechnology Alliances" (1999). Purdue CIBER Working Papers. Paper 142.

http://docs.lib.purdue.edu/ciberwp/142

This document has been made available through Purdue e-Pubs, a service of the Purdue University Libraries. Please contact epubs@purdue.edu for additional information. 
Center for International

Business Education and Research

\section{The Effect of National Culture on Partner Buyouts in Cross-Border Biotechnology Alliances}

\section{Timothy B. Folta}

Purdue University

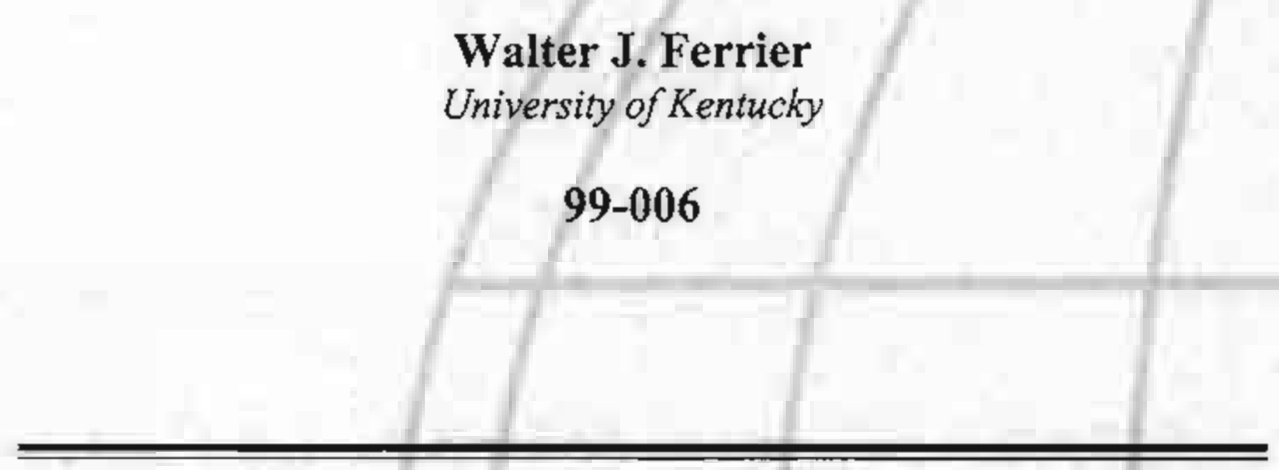

Krarnert Graduate School of Manauement Purdue University 


\title{
THE EFFECT OF NATIONAL CULTURE ON PARTNER BUYOUTS IN CROSS-BORDER BIOTECHNOLOGY ALLIANCES
}

\author{
TTMOTHY B. FOLTA \\ Krannert Graduate School of Management \\ Purdue University \\ West Lafayette, IN $47907-1310$ \\ (765) 494-9252 \\ fax: (765) 494-9658 \\ E-mail: foltat@mgmt.purdue.edu \\ WALTER J. FERRIER \\ Gatton College of Business and Economics \\ University of Kentucky \\ Lexington, KY 40506-0034 \\ (606) $257-9326$ \\ fax: (606) 257-3577 \\ E-mail: wallyf@pop.uky.edu
}

December 8, 1999

Or Theoming in the Joumal of High Technology Management Research
Revised manuscriptsuted the

We are grateful to Bob Dahlstrom, Andrew Inkpen, and two anonymous reviewers for helpful comments on an earlier version of this paper, and to Kent Miller for his help on a related project. An earlier version of this paper appeared in the 1997 Academy of Management Best Paper Proceedings. 


\title{
The Effect of National Culture on Partner buyouts in Cross-Border BIOTECHNOLOGY ALLIANCES
}

\begin{abstract}
This study examines how national culture influences the likelihood and rate of buyouts among R\&D equity alliances and joint ventures in the biotechnology industry. We hypothesize that the interaction of specific national culture attributes and cultural differences between alliance partners bear upon: a) the amount of endogenous uncertainty surrounding the potential integration of the target firm and b) the marginal rate of learning in hierarchical versus collaborative governance. Applying a competing hazard model to a sample of 173 joint ventures and minority equity collaborations in the biotechnology industry, we found that investing firms from high power distance and high uncertainty avoidance countries are more likely to buy out their alliance partners. Furthermore, greater cultural distance between alliance partners increases the likelihood of partner buyout when investing firms are from high power distance countries.
\end{abstract}


As knowledge-intensive industries become increasingly global, high tech firms are confronted with the strategic challenges, opportunities, and risks associated with cross-border alliances. Indeed, considerable managerial and scholarly attention has been paid to not only the benefits of such alliances, but also on the transactional difficulties wrought by alliance partners from different national cultures. However, most of these efforts have focused on the choice of initial governance mode (e.g., Erramilli, 1996; Kogut \& Singh, 1988; Shane, 1993). The present study is motivated in three respects. First, it is becoming clear that governance decisions may involve a strategy to sequentially invest equity in an alliance partner over time (Chang, 1995; Penner-Hahn, 1998). Second, partnerships often terminate with acquisition (Folta, 1998; Hurry, Kogut, 1991; Miller \& Bowman, 1992) as opposed to other forms of termination, such as dissolution or third party buyouts. Third, little research to date has explicitly examined whether national culture characteristics influence patterns of sequential investment and the particular mode of alliance termination.

This paper is an attempt to fill the gaps noted above by examining the role of national culture on the likelihood and rate of buyouts among R\&D equity alliances and joint ventures in the biotechnology industry. Partner buyouts are a relatively common occurrence in other knowledge-intensive industries. For example, Park and Russo (1996) found that 16.2 percent of joint ventures in the electronics industry were acquired within three years of founding, while Choi (1991) has found that 13.6 percent of minority investments ended in acquisition within one year of initiation.' Yet, despite their frequency, very few studies have explicitly treated partner buyouts as a distinct form of partnership termination. This is unfortunate because Park and Russo (1996) and Park and Ungson (1997) argue that termination by acquisition and termination by dissolution may be driven by entirely different factors. 
Like our study, Kogut (1991) examined the partner buyout decision through an option theory lens. Whereas his study examines the role of exogenous factors on buyouts, our focus is on endogenous uncertainty and the impact of national culture. To date, only Park and Ungson (1997) have examined the role of national culture on the partner buyout decision. They reveal some evidence that cultural distance increases the likelihood of buyout of the joint venture, even after controlling for other important factors such as organizational and operational differences between partners, the type of transaction, and the incidence of prior transactions between partners. Unfortunately, since their focus was termination by dissolution, they do not develop any $a$ priori theoretical arguments about the determinants of buyouts. Neither do they offer any empirical evidence regarding the effects of dimensions of culture other than cultural distance.

There are other reasons to believe that national culture may play an important role in the partner buyout decision. Chang (1995) and Hurry et al. (1992) found that sequential investment patterns were found to differ across U.S. and Japanese venture capital firms. Relative to U.S. firms, Japanese firms exhibit incremental approaches to expansion. Subsequent to news indicating venture success, Japanese venture capital firms tended to upgrade a venture investment to a joint venture or acquisition, while U.S. firms tended to sell their ownership stake. Chang (1995) questions whether the sequential investment pattern holds for western firms, reasoning that cultural and institutional background of non-western firm favor an incremental and evolutionary approach to investment. Although he does not test this proposition, he encourages study of the matter.

Hofstede (1980) defined national culture as the collective programming of the human mind. His dimensions of culture are well known and include uncertainty avoidance, power distance, masculinity-femininity, and individualism and vary considerably across countries. 
Understanding which cultural dimensions bear upon the decision to buy out a partner may shed light on several important issues. For instance, investing firms in knowledge-intensive industries would benefit from knowing how target firms from different cultures tend to respond to sequential investment behavior by partners. This ex ante knowledge may prove helpful in negotiating the terms of R\&D equity collaborations. Similarly, collaborating firms would be advised to understand whether foreign partners are likely to consider them an acquisition candidate. At a broader level, national culture may have significant implications for understanding the level and type of commitment firms make in emerging, high tech industries.

We explicitly examine the effects of national culture on the rate of partner buyout across twelve different countries. Our hypotheses are developed using aggregate measures of cultural distance by Hofstede (1980) and Ronen and Shenkar (1985), as well as more specific dimensions of culture relating to the investing firm. Using a time varying model, we test these hypotheses on a sample of minority investments and joint ventures in the biotechnology industry. In the past two decades, the biotechnology industry has grown explosively, largely due to the recognition that biotechnology could disrupt old markets, create new products, and cheapen current manufacturing process. Virtually every developed country has targeted leadership in biotechnology as a national goal (Office of Technology Assessment, 1991).

\section{BACKGROUND}

Following Kogut (1991), we characterize R\&D equity collaborations as a two-stage compound option; whereby investing firms holding a limited equity stake in a target firm can track knowledge development and (market and technological) opportunities in industries. Such equity collaborations allow firms to maintain strategic flexibility to respond to industry trends 
that are difficult to predict. Following the initial equity investment, exercise of the first stage of the option is represented by the full acquisition of a target partner. In the case of $R \& D$ partnerships where an investing firm has taken a minority equity stake, partner buyout refers to the acquisition of the R\&D supplier/partner. Partner buyout for joint ventures refers to the acguisition of the joint venture by one of the parents. ${ }^{2}$ Exercise of the second stage growth option is represented by making further discretionary investments in research or commercial opportunities resulting from the first stage commitment. In this view, equity collaborations may be initiated as a way to manage endogenous and exogenous uncertainty. Exogenous and endogenous uncertainty have different effects on the decision to commit additional capital (Dixit \& Pindyck, 1994; Rivolì \& Salorio, 1996).

Exogenous uncertainty cannot be reduced by the actions of the firm. In the case of emerging technology industries, exogenous uncertainty exists when, for example, the technological trajectory of the industry is indeterminate, industry infrastructure is lacking, and/or when key legislation affecting the industry is pending. Given these conditions, the premature acquisition of firms developing emerging technologies may impose considerable risks because the investing firm gives up the option of waiting for new information that might affect the desirability or timing of the investment. The ability to delay irreversible investment expenditures until exogenous uncertainty is resolved can be an important source of flexibility in a project and profoundly affect subsequent decisions to invest (McDonald \& Siegel, 1986).

By contrast, endogenous uncertainty can be decreased by actions of the firm. Potential sources of endogenous uncertainty for the investing firm include: expansion into unfamiliar international markets, integration of firms from diverse cultures, initiation of $R \& D$ projects that take time to develop, or inability to assess the target firm's knowledge. This form of uncertainty 
is primarily resolved by leaming; that is, actually performing the activities associated with a given project. Previous research suggests that greater endogenous uncertainty increases the value of information, and thus, increases incentives to invest in knowledge generation or acquisition (McCardle, 1985). In the presence of endogenous uncertainty, the key characteristic that makes the investment in knowledge so attractive is the ability to temporarily or permanently suspend further equity investment if the expected value of the completed projects declines due to exogenous shocks. Roberts and Weitzman (1981) have shown that if learning is enhanced by moving to the next stage of the project, there is an incentive to speed up the rate of commitment.

We argue that it is the combination of endogenous uncertainty and enhanced learning by moving to the next stage that motivates the decision to commit incrementally. This staged investment approach takes on value when internalizing the partner increases the rate of learning about the project. In this sense, exercising the buyout of a partner is comparable to the exercise of a call option on equities that pay dividends. In the presence of dividends (that come in the form of learning advantages) there may be an incentive to exercise the partner buyout option early. If the target turns out to have skills that are relevant for the partner but cannot be easily transferred across firm boundaries after a brief interchange, a buyout may be the only viable alternatives. Relative to arm's-length contracts, internalization facilitates transfer of technological capabilities because the acquirer can tap into its repository of social knowledge that structures cooperative action. According to Kogut and Zander (1992), this difference in the marginal efficiency of technology transfer constitutes the ownership advantage of the firm. ${ }^{3}$ Internalizing the partner firm may increase the efficiency of knowledge transfer, thus enabling the firm to reduce future $R \& D$ costs so that growth opportunities can be exercised at a lower cost. 
In sum, there are at least three important factors which need consideration when examining determinants of partner buyouts: (1) the level of exogenous uncertainty, (2) the level of endogenous uncertainty, and (3) the relative rate of learning inside versus outside firm boundaries. Unless endogenous uncertainty (2) is present, the relative rate of learning inside versus outside the firm (3) will have no consequence. This implies an interaction effect. In this paper, we focus explicitly on the expected interaction between endogenous uncertainty and learning. In the presence of endogenous uncertainty firms will invest sequentially when such commitment yields information about future opportunities. Firms that leam more efficiently in hierarchies are candidates to buy out their partners.

In the next section we describe our main thesis: that national culture traits and cultural differences between partners should contribute to endogenous uncertainty and rates of learning in hierarchy, and therefore, should bear upon the buyout decision.

\section{HYPOTHESES}

When valuable, but unexplored technology is resident in a target firm, investing firms differ in terms of how learning activities are to be organized. Consistent with previous research (e.g., Adler, 1991; Hofstede, 1991; Olie, 1994; Osborn \& Hagedoorn, 1997; Powell, Koput \& SmithDoerr, 1996), we argue that the cultural attributes of among investing firms are principal determinants of how firms choose to organize learning activities. We motivate our hypotheses using two of Hofstede's (1980) dimensions of national culture: power distance and uncertainty avoidance. We believe that these two dimensions are the most relevant in the study of partner buyouts for several reasons. First, as noted by Hofstede, "Of the four dimensions of national culture, power distance and uncertainty avoidance in particular affect our thinking about 
organizations. Organizing always demand the answering of two questions: (1) Who has the power to decide what? And (2) What rules or procedures will be followed to attain the desired ends?" (1991: 140). ${ }^{4}$ In contrast, Hofstede believes that while his other two dimensions, masculinity and individualism, broadly reflect the values of the national culture, they imply little about administrative practices within organizations. Consistent with the importance placed on power distance and uncertainty avoidance inside organizations, these two dimensions have been the most pervasive in research examining the behaviors of multinational corporation as evidenced by the work of Erramilli (1996), Gatignon and Anderson (1988), Kogut and Singh (1988), and Shane (1993). Finally, Hofstede (1991) argues that various combinations of power distance and uncertainty avoidance correspond directly to each of Mintzberg's (1983) preferred authority configurations and coordinating mechanisms, thereby capturing both national and organizational traits. It seems that power distance and uncertainty avoidance are the most distinctive cultural dimensions which influence organizational structure and functioning (Hoecklin, 1995).

We argue that power distance of a national culture will influence the degree to which the investing firm can learn in hierarchy. Also, uncertainty avoidance and cultural distance are argued to contribute to endogenous uncertainty in the equity partner relationship. ${ }^{5}$

\section{Power Distance and Learning Inside versus Outside the Firm}

As noted, Kogut and Zander (1992) point to the important differences in learning efficiency across governance modes. They argue that it is more efficient to transfer complex knowledge within the boundaries of a firm because learning processes are a function of shared values and assumptions. If national culture embodies social knowledge and organizing principles, it 
therefore bears upon the expected efficiency of learning subsequent to partner buyout. Firms from certain cultures may learn more efficiently when internalized, while the marginal rate of learning in hierarchy may be lower for firms from other cultures. Hall (1976) argued that cultures vary greatly in the processing of information and patterns of communication.

One cultural attribute that should influence the rate of learning in hierarchies relative to collaborations is power distance (PD). Power Distance is defined as "the extent to which members of a society accept that power in institutions and organizations is distributed unequally" (Hofstede, 1985: 348-349). As applied to organizations, control, decision making, and authority are likely to be highly centralized (Hofstede, 1980). Acquiring firms from cultures characterized as high PD operate most comfortably in hierarchy. In such countries, we expect the marginal rate of learning or technology transfer to be highest in hierarchy. Indeed, Hofstede (1991) discusses the implications of culture in an important learning context - in schools. In high PD cultures, such as Japan, learning is structured and hierarchical. By contrast, learning is loose and more unstructured in low PD cultures.

One might expect that firms from high PD cultures will move directly to outright acquisition, and avoid the first stage equity collaboration. Consistent with this expectation, Shane (1993) found that the higher the PD, the greater the likelihood of hierarchical control in transactions. More recently, Erramilli (1996) found that firms from countries with higher PD are more likely to seek majority ownership in foreign subsidiaries.

In the absence of endogenous uncertainty, firms from high PD cultures will acquire outright. However, in the presence of endogenous uncertainty, they will invest incrementally, beginning with the first stage equity collaboration. Several cultural attributes influence endogenous uncertainty. 


\section{Uncertainty Avoidance, Cultural Distance, and Endogenous Uncertainty}

The study of national culture on governance modes has predominantly focused on transaction cost explanations, where the cultural attributes or partner differences in national culture are expected to moderate the ability of managers to perceive the potential for opportunistic behavior by partners (Harrigan, 1985). As noted earlier, these transaction costs were found to be a key determinant for dissolution of equity partnerships and joint ventures and have been carefully articulated in the literature. Building on previous research, we argue that uncertainty avoidance (UA) and cultural distance (CD) are two important contributors to endogenous uncertainty.

Uncertainty avoidance (UA) is defined as the "degree to which the members of a society feel uncomfortable with uncertainty and ambiguity, which leads them to support beliefs promising certainty and to maintain institutions protecting conformity" (Hofstede, 1985: 348-349). In an organizational context, having high levels of UA leads managers to make less risky decisions and develop coping mechanisms to control uncertainty, such as developing complex systems of rules and regulations and following structured, ritual behavior (Hofstede, 1980).

Uncertainty avoidance was shown to be an important predictor of foreign market entry modes. For instance, Kogut and Singh (1988) found that multinational corporations from cultures high in UA are more likely to choose joint ventures or greenfield entry modes over full acquisitions. These authors attribute this result to the fact that the uncertainty associated with integrating the management teams of both subsidiary and parent firms is untenable. Therefore, these firms are more comfortable with either a greenfield investment or establishing an equity partnership with the host county target. Shane (1993) found that firms from high UA societies favor licensing over acquisition-type entry modes. 
Given their proclivity toward risk avoidance, it is not surprising that firms from high UA cultures prefer staged investment to outright commitment. At the same time, we expect firms from high UA cultures to benefit from a transition toward hierarchy because of the added structure in place to control opportunistic behavior. When firms are from cultures that are also high in power distance, we expect there is added incentive to internalize the target firm in order to learn about growth opportunities more efficiently. Our proposition that high PD, high UA cultures are quicker to internalize appears consistent with arguments made by Hurry et al. (1992) and Chang (1995), who asserted that Japanese fjrms, relative to U.S. firms, were more likely to eventually acquire target firms. By contrast, U.S. firms are more likely to sell their equity positions in target firms following the target firm's initial public offering. Indeed, according to Hofstede (1980), the Japanese are ranked significantly higher on both PD and UA compared to the United States.

Hypothesis 1: When established firms are from cultures ranked high in uncertainty avoidance and high in power distance, partner buyouts are more likely.

In the passage above, we argued that established firms from cultures with higher power distance learn more efficiently from their partners, and that the marginal incentive to acquire their partners is highest when the relationship is confronted with endogenous uncertainty. While uncertainty avoidance is one dimension that accentuates endogenous uncertainty, cultural distance (CD) between the partners may also influence the amount of endogenous uncertainty. Cultural distance is defined as the degree to which the home country culture of an investing firm is dissimilar from that of the host country market and firms operating therein. When there is more cultural distance between partners, the ability to effectively observe and predict opportunism among partners is hindered (Kogut, 1988), leading to higher potential transaction 
costs. Here, transaction costs represent communication and control costs embodied in cultural differences.

A large body of work has focused on initial governance choice and found cultural differences lead firms to shy away from hierarchy (Kogut and Singh, 1988; Gatignon and Anderson, 1988; Shane 1993). Other researchers have attended to the role of cultural distance on the stability of existing partnerships, finding that it contributes to a higher rate of partnership dissolution (Harrigan, 1985; Barkema, Bell, \& Pennings, 1996; Barkema, Shenkar, Vermeulen, \& Bell, 1997; Park and Ungson, 1997). More relevant to our study, Olie (1994) and Elsass and Veiga (1994) argued that the blending of diverse cultures tends to be a challenging obstacle to successful mergers. Indeed, cultural differences between firms was found to predict stress, negative attitudes toward merger, and the lack of cooperation between firms subsequent to merger (Weber, Shenkar, \& Raveh, 1996).

These findings suggest that for existing partnerships, cultural differences raise the degree of endogenous uncertainty facing partnerships, and the endogenous uncertainty facing prospects for successful mergers of the firms. The successful transfer of knowledge among culturally distant partners is an indeterminate process. This view is captured clearly by Luostarinen, who defined cultural distance as "the sum of factors creating, on the one hand, a need for knowledge, and on the other hand, barriers to the knowledge flow and hence also for flows between the home and the target countries" (1980: 131-132).

Consistent with Hypothesis 1, we argue that when endogenous uncertainty is combined with more efficient learning in hierarchy (i.e, high PD), partner buyouts should ensue. As a result, when partners are culturally distant and the investing firm is from a culture that is high in power 
distance, we expect there to be added incentive to internalize the target firm in order to learn about growth opportunities more efficiently.

Hypothesis 2: When partners are more culturally distant and the established firm is ranked high in power distance, partner buyouts are more likely.

\section{RESEARCH DESIGN}

\section{Sample}

We drew a sample of minority equity collaborations and joint ventures involving dedicated biotechnology firms (DBFs) from the North Carolina Biotechnology Center (NCBC) Actions Database. This database includes detailed information regarding over 4,000 relationships and transactions among firms in the biotechnology industry since 1978. In particular, the NCBC database includes the following transaction characteristics: a) whether the transaction involved an exchange of equity via a minority investment or a joint venture, b) the transaction date, c) the identity and number of partners involved, d) the type of partners involved (i.e., DBF, established firm, government, or university), e) each party's home country, f) the technological subfield, and g) a general description of each transaction. All transactions were cross-validated with a similar database, Bioscan. In the event that the transaction dates differed across sources, we used the earlier of the two dates.

In studying the NCBC Actions database and comparing with Bioscan we collected information on 618 equity collaborations. This original sample was reduced for three theoretical reasons. First, our compiled data were restricted to transactions involving only two parties, a target DBF domiciled in the United States and established firms having core businesses outside of biotechnology. We believe it is easier to identify the integrated manufacturer as the holder of 
the call option to acquire, a belief consistent with Hurry et al. (1992). This is particularly reasonable in cases where established firms take a minority equity stake in a DBF. These cases constitute 83.8 percent of our final sample. Determining who holds the call option is more challenging in joint ventures, where both parties contribute capital and knowledge to a jointly owned and controlled entity. ${ }^{6}$ We control for likelihood that joint ventures may be bought out by the DBF by including a joint venture dummy variable and by modeling joint venture buyouts by the DBF firm as a competing event.

Second, we restricted our sample to include only four broad subfields: a) therapeutics, b) diagnostics, c) agriculture (ag/bio), and d) supplier/specialty chemical. These subfields account for a large majority of all firms dedicated to biotechnology (Dibner, 1992). This focus on the largest subfields was necessary because of our need to have a critical mass of public firms to generate stock market indices for each subfield for our measure of exogenous uncertainty.

Finally, we focus on equity collaborations with DBFs domiciled in the United States. This enabled us to better control for exogenous events specific to country boundaries. Given these constraints on our database we identified 248 equity collaborations initiated between 1978 and 1995. Of these, we were unable to obtain the precise starting dates of 30 transactions, despite supplementing our search using Lexis/Nexus and SEC Schedule 13D filings.

We made considerable effort to verify the outcome of each partnership. If the December 1995 issue of Bioscan listed the equity partnership as ongoing, the transaction was coded as right-censored. Otherwise, a systematic search was undertaken to understand the nature of the transaction termination. NCBC and Bioscan data were supplemented with a search of Ernst \& Young Biotechnology Industry Reports, Predicast's F\&S Index of Corporate Change, 
Lexis/Nexis, and SEC Schedule 13D filings. From this effort we were able to verify the timing and outcome of 173 equity partnerships constituting our final sample.

Of the 173 transactions in our final sample, 23 were terminated by partner buyout by established firms, 39 were dissolved, 21 were terminated by other means ( 6 joint ventures were acquired by the DBF partner, 5 joint ventures were acquired by third parties, $10 \mathrm{DBFs}$ were acquired by a third party), and 90 were right censored; that is, they were still in effect at the end of $1995 .^{7}$ Table 1 provides a breakdown of the number of established firms from each country that have initiated equity collaborations with U.S. biotechnology firms. Here, we also list the outcome of these equity collaborations for each country. While equity investments are most prominently undertaken by firms in a few countries, there seems to be a clear difference in the outcomes of these collaborations. U.S firms have a high percentage of partnership dissolutions and third-party buyouts. Japanese firms and those from the United Kingdom have a significant proportion of partnerships maintained, as do firms from Switzerland, Germany, and Sweden. While these trends show clear differences in country propensities regarding equity collaboration outcomes, it is unclear whether these patterns are statistically robust when controlling for cultural factors, firm-specific factors, and those relating to the value and exogenous uncertainty regarding the technology. Furthermore, Table 1 does not consider the timing of the outcome event. For example, while it is clear that a greater percentage of Japanese firms maintained their equity stake than do U.S. firms, it does not help us understand whether Japanese firms maintained their equity relationships longer than U.S. firms.

Insert Table 1 about here 


\section{Model and Method}

We selected a competing-risk, discrete-time event history analysis to test our hypotheses. Event history models are especially appropriate for analyzing longitudinal data when the dependent variable is a discrete event and the timing of the event's occurrence is of particular interest. Competing risk is a special form of event history analysis that is used when the dependent variable has two or more outcomes and the occurrence of any one outcome removes the subject from the risk of the other outcome(s). Buyouts are one of several ways in which a partnership may be terminated. Other forms of termination include (a) dissolution of the partnership, (b) acquisition of a biotechnology firm or joint venture by a third party, and (c) acquisition of a joint venture by the biotechnology partner (rather than acquisition by the established firm). Although we do not develop explicit hypotheses regarding these other forms of termination, they do represent relevant "competing hazards" in that they preclude subsequent occurences of partner buyouts. To model the competing hazards, the hazard rate function is defined as

$$
\text { (1) } \quad h_{j}(t)=\lim _{s \rightarrow 0} P_{j}(t, t+s) / s
$$

where $h(t)$ is the hazard function associated with either partner buyout $(j=1)$, partnership dissolution $(j=2)$; or other termination $(j=3) . P_{j}(t, t+s)$ is the probability that event type $j$ occurs in the interval between $t$ and $t+s$, given that the partnership is at risk at time $t$.

Cox's (1975) partial likelihood method for parameter estimation allows us to incorporate time dependence into the model, without specifying its form. The general form for the Cox proportional hazards models estimated in this study is:

$$
\log h_{j}(t)=a_{j}(t)+\beta_{j} X(t)+\lambda_{j} Y
$$


where $a_{j}(t)$ may be any function of time, $X(t)$ and $Y$ are vectors of time dependent and time invariant explanatory variables, and $\beta_{j}$ and $\lambda_{j}$ are vectors of estimable parameters. We used TDA version 5.7 to simultaneously estimate the competing hazards model (Rohwer, 1994) with Cox's partial likelihood method. We do not provide estimates for the baseline hazard function, $a_{j}(t)$, since partial likelihood estimation discards this function. ${ }^{8}$

The three events - buyout, dissolution, and other termination - were updated monthly. The sample includes 9,843 monthly periods. The cultural variables were not time varying, but many control variables were updated monthly.

\section{Culture Variables}

Hypothesis I is tested by multiplying Hofstede's (1980) well-known measures of uncertainty avoidance and power distance to each country in our sample. Hypothesis 2 also suggests a multiplicative function involving power distance and cultural distance. Our test considers two alternative measures of cultural distance. First, following Kogut and Singh (1988), we measured Hofstede's cultural distance (HCD) as a composite index based on the each of the four cultural dimensions identified by Hofstede (1980).

We also used a second measure of cultural distance is generated from a study by Ronen and Shenkar (1985), who synthesized country clusters into nine groupings of countries with similar work-related attitudes and values. The "Anglo" cluster involves Australia, Canada, Ireland, New Zealand, South Africa, United Kingdom, and United States. All other countries in the study were grouped into the other eight clusters. Using this data, we constructed a measure of cultural distance such that when the established firm fell in the Anglo cluster, Ronen's cultural distance (RSCD) was coded " 0 ", otherwise it was coded " 1 ". 


\section{Control Variables}

Clearly, cultural factors may not dominate partner buyout decisions. We argued earlier that exogenous forces partially dictate how uncertain future payoffs are and whether a buyout option is in-the-money. Other forces specific to the industry, the investing firm, and partner relationship may also bear upon the buyout decision. In this section, we describe our attempts to control for the factors found to be important by previous researchers.

Kogut (1991) argued that exogenous forces determine whether a buyout option is in-themoney. He argued that when industry sales deviated positively from industry forecasts, joint venture partners would seek to acquire the joint venture. His annual measures, shipment growth and deviation from expected growth, are meant to capture the certainty to which joint ventures operating in an industry have appreciated in value. Our measures of exogenous variables are in the same spirit, but are measured differently. Whereas Kogut's study spanned several industries and uses annual measures, ours concentrates only on biotechnology, and we consequently focus on measuring exogenous forces within technological subfields on a monthly basis. Sales measures are unreasonable in this industry because most firms have no revenues from sales. Like Folta (1998), we measure subfield value and subfield (exogenous) uncertainty using stock market indices generated from publicly traded firm in concentrating in particular biotechnology subfields. These measures were constructed from stock prices that were gathered from the Center for Research in Security Prices data base, and are described briefly below, but in more detail in Folta (1998).

Differences in the expected value of growth opportunities across the four subfields (Therapeutic, Diagnostic, Ag/Bio, and Supplier / Specialty Chemical) with four stock indices that were created from weekly retums of nine U.S. biotechnology firms specializing in the respective 
subfields. The subfield value of firm $j$ was measured as the value of the monthly biotechnology index for subfield $m$ (when $j \in m$ ). These indices are weighted equally. Weekly values of the indices were then averaged within each month to get monthly index values for each of the four subfields. Subfield value was transformed by taking its natural logarithm to correct for positive skewness.

Exogenous uncertainty was measured as the 26-week standard deviation of the log of weekly returns for each of the four biotechnology subfield indices. The 26-week measure was chosen because it provides enough history to produce a reliable measure of volatility, without assuming constant variance over a longer period of time. Exogenous uncertainty was converted to a monthly measure by averaging the weekly standard deviations within any given month.

Substantial literature has confirmed the importance of industry structure on the choice of governance mode. ${ }^{9}$ We use average subfield R\&D expenditures divided by average total expenses to control for such effects. Conventionally, the relationship of R\&D expense is said to encourage integrative modes, such as acquisition, in order to provide adequate administrative control for coping with higher degrees of human and dedicated capital specific to a transaction. Using this logic, we might expect a positive relationship between R\&D expense and partner buyout.

Park and Ungson (1997) did not control for exogenous forces, but did find that a series of dummy variables related to the partnership influenced the buyout decision. They found that partners with the same SIC code were less likely to acquire their partners, partners having a prior relationship were more likely to end in acquisition, partnerships involving technology transfer were less likely to end in acquisition, and partnerships involving multiple products were more likely to end in acquisition. We test for some of these same effects, but not all. By definition, 
our sample includes partners from different SIC codes and partnerships involving technology transfer.

Park and Ungson (1997) have highlighted the important moderating role that prior relationships have on the effect of cultural differences on partnership dissolution. While they did not test for whether this same effect holds for partner buyouts, it may be reasonable to expect prior relationships to moderate either the degree of endogenous uncertainty or the relative rate of learning in collaboration versus hierarchy. We did not include prior relationships in our formal presentation because to the extent that cultural dimensions influence the choice of prior relationships with the partner, including a measure of prior transactions in the model would confound our ability to interpret the results. In nuns not reported, we did, include a dummy measure for prior relationships, consistent with the measure employed by Park and Ungson, but found no significant relationship in any of our models. Surprisingly, only 7.0 percent of the partnerships had a prior relationship, a number significantly below Park and Ungson's 26.0 percent in the electronics industry. Apparently, it is more common to initiate a relationship with equity transactions in the biotechnology industry.

Target firms having more commercial partners may not be attractive buyout candidates because commercial opportunities to exploit their technology may be siphoned off by others. To approximate the declining marginal threat of preemptive bidding or acquisition by each additional partner, we used the natural logarithm of the target firm's number of current commercial alliances. The number of partners was taken during the year of the event. In the event of right-censored cases, the measure was taken in the last year of the observation window. Bioscan provided this information. 
If the transaction was a joint venture an indicator variable was classified as a "1", and " 0 " if it was a minority equity investment. Joint ventures are thought to provide a real option that is more proprietary than is the case for minority investments.

Insert Table 2 about here

\section{Results}

Table 2 provides descriptive statistics and correlations for the variables. Because of concems of multicollinearity between Uncertainty Avoidance and the Cultural Distance variables, as well as the small number of events, we opted to present three full models relating to our hypotheses.

Table 3 presents the full (columns 2, 4,6) and reduced (columns 1, 3, 5) models with the parameter estimates for the hazard of partner buyout. To ascertain the degree of model fit, likelihood ratio tests were performed on the incremental and full models. Each test produced a chi-square statistic well above the critical value $(p<0.001)$, indicating that the overall fit is good. The bypotheses for the individual interaction coefficients are tested under one-tail t-tests. In each of the full models, the hypothesized interaction is positive and significant. These findings are consistent with our expectations.

\section{Insert Table 3 about here}

In model 2 , the positive coefficient on the interaction $(p<0.05)$ between Uncertainty Avoidance and Power Distance is consistent with the expectations offered in hypothesis 1. It suggests that established firms from cultures higher in UA and PD should be more likely to buy out their partners. 
In models 4 and 6 , both the positive coefficient on the interaction $(p<0.10)$ between Hofstede's Cultural Distance and Power Distance as well as the positive coefficient on the interaction ( $\mathrm{p}<0.01$ ) between Ronen's Cultural Distance and Power Distance are consistent with the expectations offered in hypothesis 2 . It suggests that when partners that are more culturally distant and established investors are higher in Power Distance there is an increased likelihood of partner buyout.

Since the remaining variables in the models have no hypotheses related to them, we use a two-tailed test to assess the significance of relationships. The only variable that demonstrated a significant effect was Target Firm's Number of Partners. As was expected, it was negatively related to the likelihood of partner buyout. This variable should approximate how proprietary the buyout option is. The more partners a target partner has, the less proprietary is the option. The variables relating to exogenous uncertainty, subfield value, and subfield R\&D expense were not significant. Neither was the indicator variable distinguishing joint ventures from minority investments.

Table 3 also includes the competing hazard results for partnership dissolution in columns 7 10. These results indicate that Uncertainty Avoidance and Ronen's Cultural Distance is negatively related to the likelihood of dissolution. The latter result is consistent with those found by Park and Ungson (1997) in studying the electronics industry. They did not examine the effect of Uncertainty Avoidance. Furthermore, in comparison with the findings for the partner acquisition models, these findings demonstrate that national culture attributes influence partner dissolution differently. ${ }^{10}$

Consistent with previous studies, we focused mainly on aggregate measures of cultural distance. However, Hofstede (1980) suggests that partner differences for power distance, 
uncertainty avoidance, masculinity, and individuality may represent important areas of conflict among partners. In addition, recent research suggests that absolute measures of cultural "distance" may obfuscate directional differences among individual cultural attributes (O'Grady \& Lane, 1996). As a result, we also tested measures of cultural distance that are specific to indjvidual attributes. These variables are calculated the same way as illustrated in equation 3 , however, they only apply to a single attribute.

Insert Table 4 about here

Table 4 reports the parameter estimates for cultural distance measures that are specific to Hofstede's individual attributes of national culture." We provide only the full models including the interaction. In model 1, the positive coefficient for the interaction between Power Distance and Cultural Distance/Partner Differences in Power Distance is consistent with bypothesis 2. Also consistent with Hypothesis 2 is the positive coefficient for the interaction between Power Distance and Cultural Distance/Partner Differences in Uncertainty Avoidance. The interactions in models 3 and 4 involving differences in Individuality and Masculinity, respectively, were not significant. These findings support our a priori expectation focus on Uncertainty Avoidance and Power Distance, and also support the arguments by Hofstede that these two dimensions of national culture have the greatest bearing on organizational phenomena.

Given that partner differences in Uncertainty Avoidance and Power Distance seem to be the two dimensions of national culture which best explain organizational phenomenon, we created a cultural difference measure incorporating both of those dimensions. The model is illustrated in column 5 of Table 4. The positive and significant interaction $(\mathrm{p}<0.05)$ is consistent with expectations for hypothesis 2 . 


\section{Discussion}

The role of national culture on governance choice has been frequently studied. However, these studies have largely focused on the initial governance decision or partnership termination, giving little attention specifically to partner buyouts. This oversight is consequential, given the high incidence of acquisition of joint venture and equity partners. By explicitly considering the role of national culture on partner buyouts, we extend a growing body of literature that examines the incremental nature of investments in joint ventures and partner firms in knowledge-intensive industries. Although we are the not the first to characterize equity collaborations are compound options, our study is the first to attempt to theoretically explain the role of national culture on partner buyout. Partner buyout represents the exercise of the first stage option, while future discretionary investments represent the exercise of the second stage option. Real option theory suggests that firms should choose to invest incrementally in the face of endogenous uncertainty. It also suggests that firms will be more likely to commit to the next stage when they can learn more by committing, thereby reducing endogenous uncertainty.

We have built upon option theory to suggest that partner buyouts will be influenced by three factors: exogenous variables, endogenous uncertainty, and the rate of learning inside versus outside the firm. Our central argument is that attributes of national culture bears upon these latter two factors. Specifically, we argue that both uncertainty avoidance and cultural distance increases endogenous uncerlainty. This is likely due to the inability to perceive the potential for opportunistic behavior by partners, or information asymmetry between partners. As a result of such uncertainty, established firms will shy away from aggressive commitment to growth opportunities, they will invest incrementally. Firms from cultures that are high in power distanceare expected to transition to hierarchical governance because it is in hierarchies that they operate 
and learn most efficiently about growth opportunities. Thus, it is the combination of high endogenous uncertainty and the ability (or prospects) to learn more efficiently after internalizing the partner that leads to partner buyout.

Our empirical findings are consistent with the expectations noted above. Uncertainty avoidance and cultural distance are argued to contribute to endogenous uncertainty, while power distance is argued to impact the relative rate of learning in hierarchy relative to collaborations. Established firms from high UA home country cultures are more likely to buy out partners when they are also high in PD. Partners that are culturally distant are more likely to buy out partners when they are also high in PD. These findings suggest that it is the combination of endogenous uncertainty and efficient learning at the next stage that promote commitment via partner buyout. They are robust to different measures of cultural distance emanating from work by Hofstede (1980) and Ronen and Shenkar (1985). Distance measures using Hofstede's dimensions of Uncertainty Avoidance and Power Distance seem to mostly explain endogenous uncertainty.

Upon examination of country values for UA, Japan is among the world's most uncertainty avoidant cultures (about 1.5 standard deviations above the mean; see Hofstede, 1980: 315). According to our research findings, Japanese firms might be expected to exhibit high levels of anxiety with respect to both endogenous uncertainty and exogenous uncertainty. Therefore, Japanese firms will place greater intrinsic and extrinsic value on maintaining the equity collaboration. Indeed, our findings suggest that firms high in UA (including those from Japan) are less likely to acquire their collaboration partners and less likely to dissolve the partnership. These findings support those of Hurry et al. (1992) and Chang (1995) who found that Japanese firms were more likely than U.S. firms to retain their holdings in international joint ventures. 


\section{A Framework for Understanding Intentions of Foreign Partners}

Using Hofstede's dimensions of Uncertainty Avoidance and Power Distance there is potential to create a broad framework by which future studies can examine partner buyout decisions in particular, and sequential investment more generally. In Table 5 we located countries based on only two measures: Uncertainty Avoidance and Power Distance. Since these measures are specific to the established firm, and not the relationship between partners, we can develop a general framework of tendencies toward partner buyout. Since firms domiciled in France and Japan are high in both Uncertainty Avoidance and Power Distance, we expect them to be most likely to buy out their partners. The second most likely group to buy out partners consists of firms high in Uncertainty Avoidance and medium in Power Distance: Germany, Italy, and Switzerland. Finally, firms from countries that are medium in both PD and UA (Australia, Canada, the United Kingdom, or the United States) may also demonstrate a notion for partner buyouts, although to a lesser extent. Established firms from other countries are less likely to exhibit a tendency to buy out their partners either because there is low power distance or low uncertainty avoidance.

Insert Table 5 about here

Of course, cultural distance is not depicted in Table 5. According to our theoretical expectations, even established firms from uncertainty avoidance cultures may display a tendency to buy out partners if they are culturally distant. The expectations presented in Table 5 can be altered to reflect cultural distance. For example, France and Japan are especially likely candidates for buyouts of U.S. partners because they are high on all three cultural attributes: Power Distance, Uncertainty Avoidance, and Cultural Distance. The framework can be extended 
to partnerships not involving United States target firms. For example, the tendency for Japanese firms to acquire Japanese partners may be muted somewhat because of a lack of cultural distance. At the same time, because of high cultural distance, firms from Australia, Canada, the United Kingdom, and the United States may demonstrate an increased tendency for acquiring Japanese partners. We believe that these propositions are very deserving of more attention in samples involving multiple industries and entry into multiple countries.

We should note several limitations of this study. Although our sampling methodology was comprehensive for nearly the entire life of the biotechnology industry, the number of partner buyout events is small. Nevertheless, we managed to attain statistical significance for our key variables and stability across a number of models containing firm-level and/or industry-level control variables. A larger sample would allow disaggregation of joint ventures and minority equity partnerships. Our study focused on a single industry, and sub-segments within that industry. While these segments are distinct from one another, future research should attempt to verify the expected relationships in other industries, including both $R \& D$ intensive and more stable industries.

Parkhe (1991) suggests that formal training programs can enhance cultural understanding and may moderate the relationship between cultural variables and the duration of global alliances. These integrating mechanisms may have an important influence on the relative rate of learning in joint ventures versus acquisition, and hence, may play a role in the buyout decision. Unfortunately, since we lacked data on the extent of cross-cultural training programs, we could not examine this issue. However, we believe that our theoretical framework offers an interesting new opportunity to ascertain how integrating mechanisms may influence the relatively unexplored phenomena of partner buyouts. 
Previous research has demonstrated that companies use collaborations when partnering with culturally distant partners. Thus, our sample of equity collaborations may reflect some restricted range of cultural distance. Indeed, means scores of cultural distance varied significantly when we examined a broader sample of transactions involving both equity collaborations (0.64) and outright acquisitions (.036). Thus, our study, and any study examining the effect of national culture on partner buyout will suffer from such a bias. This will tend to weaken the results for cultural distance. We have demonstrated, however, that even though we have sampled culturally distant partners, power distance acts to moderate the partner buyout decision.

Overall, our study suggests that cultural attributes of the investing firm and cultural differences between the investing and target firms play a significant role in predicting the rate at which partner buyouts occur. It suggests that firms find value in flexibility in the presence of endogenous uncertainty, and are quicker to exercise when buyout enhances the potential rate of learning. The hypotheses developed here and the results we found offer some promising new directions for future empirical research. 


\section{ENDNOTES}

1 Other evidence of partner buyouts include Kogut (1989), who found that 24.0 percent of joint ventures were acquired by a partner within seven years, and Mikkelson and Ruback (1985), who discovered that 13.6 percent of firms having initiated minority investments either acquired or attempted to acquire their partner within three years of taking an initial equity stake.

${ }^{2}$ We are not without precedent in defining the scope of this research to encompass both joint ventures and minority investments (e.g., Hennart, 1991; Pisano, 1989).

${ }^{3}$ For Williamson (1985), the ownership advantage of the firm results from its superior mechanisms for coping with opportunism.

${ }^{4}$ Although Hofstede is largely famous for his 1980 IBM national culture study, he and his colleagues later found several links between national culture and organizational culture (Hofstede, 1991; Hofstede, Neuijen, Ohayv, \& Sanders, 1990). In particular, the organizational culture dimensions of need for authority and need for security correlated strongly with power distance and uncertainty avoidance, respectively. Therefore, we restrict our analysis to only power distance and uncertainty avoidance - cultural dimensions that capture both national and organizational traits.

${ }^{5}$ We are grateful to a reviewer who emphasized that cultural distance and uncertainty avoidance are not equaled to endogenous uncertainty. Indeed, they are merely constructs that contribute to endogenous uncertainty. As pointed out on pages 6-7, endogenous uncertainty may be represented by many factors.

${ }^{6}$ Either partner may hold the option to acquire the joint venture. Who is most likely to exercise the option in the case of joint ventures turns not only on the strategic intentions of the partners, but the relative competitive strengths of the partners--the partner possessing unique complementary resources being the more likely to acquire the weaker partner's stake (Hurry, 1993). Integrated firms investing in biotechnology have downstream skills in marketing and distribution, and regulatory savvy (Arora \& Gambardella, 1990). Although dedicated biotechnology firms (DBFs) have important R\&D capabilities, they frequently lack the cash needed to invest in acquisitions. Furthermore, most integrated manufacturers of pharmaceuticals, chemicals, and agriculture have a major goal of acquiring technical knowledge in biotechnology, while only a handful of DBF's aspire to become fully integrated (Office of Technology Assessment, 1991). In our sample we found that six joint ventures were acquired by the integrated partner and six joint ventures that were acquired by the DBF. Our focus on the established furm as the holder also rests on our theoretical interest in understanding when firms are more likely to commit to internalizing technical knowledge to capitalize on emerging technologies, and not downstream skills.

${ }^{7}$ Although the rate of acquisition ( 6.9 percent) by year three appears somewhat below rates found in studies noted on page 3 , to make our rate comparable we must also include acquisitions by the DBF partner and allow for a three year window for the event to take place. In making that adjustment we find that 10.0 percent of the total sample ( 14.8 percent of joint ventures and 8.9 percent of minority investments) was terminated by acquisition by one of the partners within 36 
months. This, then, is consistent with previous studies.

${ }^{8}$ The Cox method uses only information about the relative order of duration times, instead of the exact timing of events. Hence, the Cox method involves some loss of information, potentially inhibiting model estimation. This same feature makes the Cox model an attractive one when one has no prior expectations about time dependence. Another reason to question the validity of the Cox partial likelihood model for our data is that our number of events is relatively few. Although partial likelihood models are asymptotically efficient when the sample size is large (Efron, 1977), when the sample size is small, the precision of the partial likelihood estimates can be much less than that for maximum likelihood estimates (Coleman, 1981). We estimated a second model using maximum likelihood. Maximum likelihood methods require specification of a baseline hazard function. We chose the exponential speciffcation because it is the parametric equivalent to the Cox method. The results from that estimation produced a pattern of relations identical to those found via the Cox estimation, with slightly less significance. This supplemental analysis provided evidence for the robustness of the results reported in this paper.

${ }^{9}$ We also examined the effect of industry structure using number of rivals active in each of the 123 product areas for each year throughout the publication of Bioscan (1987-1995). We did not include this variable in the formal presentation because it had no substantive impact on the model, and there was substantial colinearity with other variables in the model (R\&D Expense and Subfield Value).

${ }^{10}$ We also examined whether dissolution was influenced by an interaction between cultural distance and power distance, and uncertainty avoidance and power distance. Log likelihood ratio tests indicated no such interaction existed.

" Weber, Shenkar, and Raveh (1996) also used distance measures for Hofstede's individual culture attributes, but focused on the impact on mergers and acquisition, not partner buyouts. 


\section{REFERENCES}

Adler, N. J. 1991. International dimensions of organizational behavior. Belmont, CA: Wadworth Publishing.

Arora, A. \& Gambardella, A. 1990. Complementarity and external linkages: The strategies of the large firms in biotechnology. The Joumal of Industrial Economics, 38: 361-379.

Barkema, H., Bell, J. \& Pennings, J. 1996. Foreign entry, cultural barriers, and learning. Strategic Management Journal, 17: 151-166.

Barkema, H., Shenkar, O., Vermeulen, F. \& BelI, J. 1997. Working abroad, working with others: How firms learn to operate international joint ventures. Academy of Management Joumal, 40: 426-442.

Chang, S.J. 1995. International expansion strategy of Japanese firms: Capability building through sequential entry. Academy of Management Journal, 38(2): 383-407.

Choi, D. 1991. Toehold acquisitions, shareholder wealth, and the market for corporate control. Joumal of Financial and Quantitative Analysis, 26: 391-407.

Coleman, J.S. 1981. Longitudinal data analysis. New York: Basic Books.

Cox, D.R. 1975. Partial likelihood. Biometrika, 62: 269-76.

Dibner M.D. 1992. U.S. biotechnology and pharmaceuticals. BioPharm, 5(8): 24-28.

Dixit, A. K. \& Pindyck, R. S. 1994. Investment under uncertainty. Princeton, New Jersey: Princeton University Press.

Efron, B. 1977. The efficiency of Cox's likelihood function for censored data. Journal of the American Statistical Association, 72: 557-65.

Elsass, P.M. \& Viega, J.F. 1994. Acculturation in acquired organizations: A force-field perspective. Human Relations, 47: 431-453.

Erramilli, K. 1996. Nationality and subsidiary ownership patterns in multinational corporations. Journal of International Business Studies, 27:225-248.

Folta, T.B. 1998. Governance and Uncertainty: The tradeoff between administrative control and commitment. Strategic Management Journal, 19: 1007-1028. 
Gatignon, H. \& Anderson, E. 1988. The multinational corporation's degree of control over foreign subsidiaries: An empirical test of transaction cost explanations. Journal of Law. Economics, and Organization, 4(2): 305-336.

Hall, E.T. 1976. Beyond culture. Garden City, NY: Anchor Books/Doubleday

Harrigan, K. 1985. Strategies for joint ventures. Lexington, MA: Lexington Books.

Hennart, J.F. 1991. The transaction cost theory of joint ventures: An empirical study of Japanese subsidiaries in the United States. Management Science, 37(4): 483-497.

Hoecklin, L. 1995. Managing cultural differences: Strategies for competitive advantage. Reading, MA: Addison-Wesley.

Hofstede, G. 1980. Culture's consequences: International differences in work-related values. Beverly Hills: Sage.

Hofstede, G. 1985. The interaction between national and organizational value systems. Journal of Management Studies, 22: 347-357.

Hofstede, G., Neuijen, B., Ohayv, D., \& Sanders, G. 1990. Measuring organizational cultures: A qualitative and quantitative study across twenty cases. Administrative Science Quarterly, 35: 286-316.

Hofstede, G. 199 I. Cultures and organizations: Software of the mind. Berkshire, UK: McGrawHill.

Hurry, D. 1993. Restructuring in the global economy: The consequences of strategic linkages between Japanese and U.S. firms. Strategic Management Joumal, 14: 69-82.

Hurry, D., Miller, A. T., \& Bowman, E. H. 1992. Calls on high-technology: Japanese exploration of venture capital investments in the United States. Strategic Management Journal, 13: 85-101.

Kogut, B. 1988. Joint ventures: Theoretical and empirical perspectives. Strategic Management Joumal, 9(4): 319-332.

Kogut, B. 1989. The stability of joint ventures: Reciprocity and competitive rivalry. The Joumal of Industrial Economics, 38: 183-198.

Kogut, B. 1991. Joint ventures and the option to expand and acquire. Management Science, 37 : 19-33.

Kogut, B. \& Singh, H. 1988. The effect of national culture on the choice of entry mode. Journal of International Business Studies, 49: 411-430. 
Kogut, B. \& Zander, U. 1992. Knowledge of the firm, combinative capabilities and the replication of technology. Organizational Science, 3: 383-397.

Kogut, B. \& Zander, U. 1993. Knowledge of the firm and the evolutionary theory of the multinational corporation. Journal of International Business Studies, Fourth Quarter: 625 645 .

Luostarinen, R. 1980. Internationalization of the firm: An empirical study of the internationalization of firms with small and open domestic markets with special emphasis on lateral rigidity as a behavioral characteristic in strategic decision-making. Helsinki: Helsinki School of Economics.

McCardle, K. 1985. Information acquisition and the adoption of new technology. Management Science, 31(11): 1372-1389.

McDonald, R. \& Siegel, D. 1986. The value of waiting to invest. Quarterly Journal of Economics, 101: 707-28.

Mikkelson, W. H. \& Ruback, R. S. 1985. An empirical analysis of the interfirm equity investment process. Journal of Financial Economics, 14: 523-553.

Mintzberg, H. 1983. Structure in fives: Designing effective organizations. Englewood Cliffs, NJ: Prentice Hall.

O'Grady, S. \& Lane, H. 1996. The psychic distance paradox. Journal of International Business Studies, 27: 309-334.

Office of Technology Assessment. 1991. Biotechnology in a global economy. Congress of the United States, Washington, D.C.

Olie, R. 1994. Shades of culture and institutions in international mergers. Organizational Studies, 15: 381-405.

Osborn, R. \& Hagedoorn, J. 1997. The institutionalization and evolutionary dynamics of interorganizational alliances and networks. Academy of Management Journal, 40: 261-278.

Park, S. \& Russo, M. 1996. When competition eclipses cooperation: An event history analysis of joint venture failure. Management Science, 42: 875-890.

Park, S. \& Ungson, G. 1997. The effect of national culture, organizational complementarity, and economic motivation on joint venture dissolution. Academy of Management Journal, 40: 279-307. 
Parkhe, A. 1991. Interfirm diversity, organizational learning, and longevity in global strategic alliances. Journal of International Business Studies, Fourth Quarter: 579-601.

Penner-Hahn, J. 1998. Firm and environmental influences on the mode and sequence of foreign. research and development activities. Strategic Management Journal, 19: 149-168.

Pisano, G. 1989. Using equity participation to support exchange: Evidence from the biotechnology industry. Journal of Law, Economics, and Organization, 5(1): 109-126.

Powell, W., Koput, K., \& Smith-Doer, L. 1996. Interorganizational collaboration and the locus of innovation: Networks of learning in biotechnology. Administrative Science Quarterly, 41: 116-145.

Rivoli, P. \& Salorio, E. 1996. Foreign direct investment and investment under uncertainty. Journal of International Business Studies, 27: 335-358.

Roberts, K. \& Weitzman, M. 1981. Funding criteria for research, development, and exploration projects. Econometrica, 49: 1261-88.

Rohwer, G. 1994. Parametric transition rate models. TDA Working Paper 5-7, University of Bremen.

Ronen, S. \& Shenkar, O. 1985. Clustering countries on attitudinal dimensions: A review and synthesis. Academy of Management Review, 10: 434-454.

Shane, S. 1993. The effect of cultural differences in the perception of transaction costs on national differences in the preference for licensing. Academy of Management Best Paper Proceedings, 122-126.

Weber, Y., Shenkar, O. \& Raveh, A. 1996. National and corporate cultural fit in mergers / acquisitions: An exploratory study. Management Science, 42(8): 1215-1227.

Williarnson, O. E. 1985. The economic institutions of capitalism. New York: Free Press. 
Table 1: Cultural Measures and Outcomes of Equity Collaborations by Country of Corporate Headquarters

\begin{tabular}{|c|c|c|c|c|c|c|c|c|c|c|}
\hline \multirow[b]{2}{*}{ Country } & \multicolumn{4}{|c|}{ Cultural Measures } & \multicolumn{6}{|c|}{$\begin{array}{c}\text { Outcomes of Equity Collaborations } \\
\text { Actual (Percent) }\end{array}$} \\
\hline & UA & $\mathrm{PD}$ & $\begin{array}{l}\text { Hofstede's } \\
\text { Cult. } \\
\text { Distance }\end{array}$ & $\begin{array}{l}\text { Ronen's } \\
\text { Cultural } \\
\text { Category }\end{array}$ & $\begin{array}{l}\text { Partner } \\
\text { Buyout }\end{array}$ & $\begin{array}{l}\text { Partnership } \\
\text { Dissolution }\end{array}$ & $\begin{array}{l}3^{\text {rd }} \text { Party } \\
\text { Buyout }\end{array}$ & $\begin{array}{l}\text { Partnerships } \\
\text { Maintained }\end{array}$ & Total & $\begin{array}{c}\text { \# of } \\
\text { Establish } \\
\text {-ed Firms }\end{array}$ \\
\hline Australia & 51 & 36 & 0.026 & Anglo & $1(100 \%)$ & $0(0 \%)$ & $0(0 \%)$ & $0(0 \%)$ & 1 & 1 \\
\hline Canada & 48 & 39 & 0.138 & Anglo & $0(0 \%)$ & $1(50 \%$ & $1(50 \%)$ & $0(0 \%)$ & 2 & 1 \\
\hline Denmark & 23 & 18 & 1.745 & Nordic & $1(50 \%)$ & $1(50 \%)$ & $0(0 \%)$ & $0(0 \%)$ & 2 & 2 \\
\hline France & 86 & 68 & 1.617 & Latin Europe & $2(40 \%)$ & $0(0 \%)$ & $0(0 \%)$ & $3(60 \%)$ & 5 & 2 \\
\hline Germany & 65 & 35 & 0.630 & Germanic & $0(0 \%)$ & $0(0 \%)$ & $2(28.6 \%)$ & $5(71.4 \%)$ & 7 & 2 \\
\hline Ireland & 35 & 28 & 0.530 & Anglo & $1(50 \%)$ & $1(50 \%)$ & $0(0 \%)$ & $0(0 \%)$ & 2 & 1 \\
\hline Italy & 75 & 50 & 0.650 & Latin Europe & $1(50.0 \%)$ & $0(0 \%)$ & $0(0 \%)$ & $1(50.0 \%)$ & 2 & 2 \\
\hline Japan & 92 & 54 & 3.104 & Far East & $3(13.6 \%)$ & $3(13.6 \%)$ & $1(4.6 \%)$ & $15(68.2 \%)$ & 22 & 17 \\
\hline Norway & 50 & 31 & 1.667 & Nordic & $0(0 \%)$ & $1(100 \%)$ & $0(0 \%)$ & $0(0 \%)$ & 1 & 1 \\
\hline Sweden & 29 & 31 & 1.859 & Nordic & $1(12.5 \%)$ & $2(25.0 \%)$ & $1(12.5 \%)$ & $4(50.0 \%)$ & 8 & 4 \\
\hline Switzerland & 58 & 34 & 0.528 & Germanic & $3(17.7 \%)$ & $1(5.8 \%)$ & $3(17.2 \%)$ & $10(58.8 \%)$ & 17 & 3 \\
\hline United Kingdom & 35 & 35 & 0.083 & Anglo & $0(0 \%)$ & $1(7.1 \%)$ & $0(0 \%)$ & $13(92.9 \%)$ & 14 & 3 \\
\hline United States & 46 & 40 & 0.000 & Anglo & $10(11.1 \%)$ & $28(31.1 \%)$ & $13(14.5 \%)$ & $39(43.3 \%)$ & 90 & 34 \\
\hline Total & & & & & $23(13 \%)$ & $39(23 \%)$ & $21(12 \%)$ & $90(52 \%)$ & 173 & 73 \\
\hline
\end{tabular}


Table 2: Descriptive Statistics and Correlation Matrix ${ }^{\mathrm{a}}$

\begin{tabular}{|c|c|c|c|c|c|c|c|c|c|c|c|c|c|c|}
\hline & & Mean & S.D & 1 & 2 & 3 & 4 & 5 & 6 & 7 & 8 & 9 & 10 & 11 \\
\hline 1. & Uncertainty A voidance & 53.143 & 18.157 & & & & & & & & & & & \\
\hline 2. & Hofstede's Cultural Distance & 0.632 & 1.078 & $0.786 *$ & & & & & & & & & & \\
\hline 3. & Ronen's Cultural Distance & 0.343 & 0.475 & $0.653 *$ & $0.795 *$ & & & & & & & & & \\
\hline 4. & Power Distance & 40.804 & 8.141 & $0.823 *$ & $0.572 *$ & $0.268 *$ & & & & & & & & \\
\hline 5. & $\mathrm{UA} * \mathrm{PD}$ & 2290.158 & 1283.659 & $0.964 *$ & $0.794 *$ & $0.573 *$ & $0.918 *$ & & & & & & & \\
\hline 6. & Hofstede's CD * PD & 30.817 & 57.567 & $0.869 *$ & $0.977^{*}$ & $0.728 *$ & $0.711 *$ & $0.893 *$ & & & & & & \\
\hline 7. & Ronen's CD * PD & 15.023 & 22.129 & $0.835 *$ & $0.879 *$ & $0.940^{*}$ & $0.568 *$ & $0.807 *$ & $0.876 *$ & & & & & \\
\hline 8. & Exogenous Uncertainty & 0.3191 & 0.103 & $-0.035 *$ & -0.006 & -0.004 & $-0.027 *$ & $-0.029 *$ & -0.014 & -0.013 & & & & \\
\hline & Subfield Value & 5.736 & 1.095 & $0.050^{*}$ & $0.050^{*}$ & $0.099 *$ & $0.026 *$ & $0.052 *$ & $0.056 *$ & $0.106 *$ & $0.098 *$ & & & \\
\hline & Subfield R\&D Expense & 41.423 & 11.846 & $0.135 *$ & 0.188 * & $0.201 *$ & $0.052 *$ & $0.133 *$ & $0.186 *$ & $0.205 *$ & $0.107 *$ & $0.328 *$ & & \\
\hline 11. & Target's \# of Partners & 3.118 & 1.625 & $-0.030 *$ & $-0.177 *$ & $-0.040 *$ & $-0.128 *$ & $-0.112 *$ & $-0.173 *$ & $-0.086 *$ & -0.003 & $-0.021 *$ & $-0.076 *$ & \\
\hline 12. & Joint Venture & 0.170 & 0.375 & $0.067 *$ & $0.035 *$ & $0.072 *$ & $0.053^{*}$ & $0.058 *$ & $0.039 *$ & $0.073^{*}$ & $-0.035 *$ & $-0.109 *$ & $-0.084 *$ & $0.164 *$ \\
\hline
\end{tabular}

* Pearson correlations are significant at $p<0.05$.

a Correlations are calculated using pooled cross-sectional and time-series data covering 173 equity partnerships and 9,843 one-month periods. 
Table 3: Partial Likelihood Estimates for Hazard of Partner Buyout and Partnership Dissolution

\begin{tabular}{|c|c|c|c|c|c|c|c|c|c|c|}
\hline \multirow[b]{2}{*}{ Variable Name } & \multicolumn{6}{|c|}{ Partnership Acquisition } & \multicolumn{4}{|c|}{ Partnership Dissolution } \\
\hline & (1) & (2) & (3) & (4) & (5) & (6) & $(\bar{T})$ & (8) & (9) & $(0)$ \\
\hline Uncertainty Avoidance & $\begin{array}{l}-0.0278 \\
(0.0197)^{a}\end{array}$ & $\begin{array}{l}-0.0338 \\
(0.0356)\end{array}$ & & & & & $\begin{array}{l}-0.0179 \dagger \\
(0.0102)\end{array}$ & & & \\
\hline Hofstede's Cultural Distance & & & $\begin{array}{c}0.1899 \\
(0.2100)\end{array}$ & $\begin{array}{l}-0.7904 \\
(0.6699)\end{array}$ & & & & $\begin{array}{l}-0.2919 \\
(0.1823)\end{array}$ & & \\
\hline Ronen's Cultural Distance & & & & & $\begin{array}{c}0.6992 \\
(0.4355)\end{array}$ & $\begin{array}{l}-2.7992^{*} \\
(1.5773)\end{array}$ & & & $\begin{array}{l}-0.8394^{*} \\
(0.4066)\end{array}$ & \\
\hline Power Distance & $\begin{array}{l}-0.0660 \\
(0.0420)\end{array}$ & $\begin{array}{l}-0.0996^{*} \\
(0.0392)\end{array}$ & $\begin{array}{l}-0.0262 \\
(0.0246)\end{array}$ & $\begin{array}{l}-0.0510^{*} \\
(0.0254)\end{array}$ & $\begin{array}{l}-0.0215 \\
(0.0210)\end{array}$ & $\begin{array}{l}-0.0902^{* *} \\
(0.0306)\end{array}$ & & & & $\begin{array}{l}-0.0315 \\
(0.0195\end{array}$ \\
\hline $\mathrm{UA} * \mathrm{PD}$ & & $\begin{array}{l}0.0012 * * \\
(0.0006)\end{array}$ & & & & & & & & \\
\hline Hofstede's CD * PD & & & & $\begin{array}{l}0.0219 \dagger \bullet \\
(0.0136)\end{array}$ & & & & & & \\
\hline Ronen's CD * PD & & & & & & $\begin{array}{c}0.0903^{* *} \\
(0.0388)\end{array}$ & & & & \\
\hline Exogenous Uncertainty & $\begin{array}{l}-2.0209 \\
(2.2834)\end{array}$ & $\begin{array}{l}-1.8379 \\
(2.2631)\end{array}$ & $\begin{array}{l}-2.3513 \\
(2.2945)\end{array}$ & $\begin{array}{l}-1.8959 \\
(2.3054)\end{array}$ & $\begin{array}{l}-2.3481 \\
(2.2896)\end{array}$ & $\begin{array}{l}-1.8051 \\
(2.2970)\end{array}$ & $\begin{array}{r}2.6796 \dagger \\
(1.5885)\end{array}$ & $\begin{array}{c}3.1736 \\
(1.6273)\end{array}$ & $\begin{array}{c}3.2658^{*} \\
(1.6409)\end{array}$ & $\begin{array}{c}2.5622 \\
(1.5882)\end{array}$ \\
\hline Subfield Value & $\begin{array}{l}-0.0581 \\
(0.1951)\end{array}$ & $\begin{array}{l}-0.0775 \\
(0.2020)\end{array}$ & $\begin{array}{l}-0.0612 \\
(0.1962)\end{array}$ & $\begin{array}{l}-0.0666) \\
(0.1976)\end{array}$ & $\begin{array}{l}-0.0736 \\
(0.1954)\end{array}$ & $\begin{array}{l}-0.1045 \\
(0.1988)\end{array}$ & $\begin{array}{c}0.1934 \\
(0.1637)\end{array}$ & $\begin{array}{c}0.2007 \\
(0.1631)\end{array}$ & $\begin{array}{c}0.2183 \\
(0.1638)\end{array}$ & $\begin{array}{c}0.2045 \\
(0.1634)\end{array}$ \\
\hline Subfield R\&D Expense & $\begin{array}{l}-0.0131 \\
(0.0165)\end{array}$ & $\begin{array}{l}-0.0217 \\
(0.0174)\end{array}$ & $\begin{array}{l}-0.0143 \\
(0.0170)\end{array}$ & $\begin{array}{l}-0.0[75 \\
(0.0172)\end{array}$ & $\begin{array}{l}-0.0154 \\
(0.0168)\end{array}$ & $\begin{array}{l}-0.0220 \\
(0.0174)\end{array}$ & $\begin{array}{c}0.0148 \\
(0.0164)\end{array}$ & $\begin{array}{c}0.0140 \\
(0.0162)\end{array}$ & $\begin{array}{c}0.0151 \\
(0.0164)\end{array}$ & $\begin{array}{c}0.0124 \\
(0.0162)\end{array}$ \\
\hline Target Firm's \# of Partners & $\begin{array}{l}-0.4819 * * \\
(0.1627)\end{array}$ & $\begin{array}{l}-0.3797^{*} \\
(0.1678)\end{array}$ & $\begin{array}{l}-0.4524^{* *} \\
(0.1659)\end{array}$ & $\begin{array}{l}-0.4213 * * \\
(0.1632)\end{array}$ & $\begin{array}{l}-0.4567 * * \\
(0.1637)\end{array}$ & $\begin{array}{l}-0.3884^{*} \\
(0.1622)\end{array}$ & $\begin{array}{l}-0.4584 * * * \\
(0.1291)\end{array}$ & $\begin{array}{l}-0.4982 * * * \\
(0.1303)\end{array}$ & $\begin{array}{l}-0.4851^{* * *} \\
(0.1310)\end{array}$ & $\begin{array}{l}-0.4775 * * * \\
(0.1289)\end{array}$ \\
\hline Joint Venture & $\begin{array}{c}0.6862 \\
(0.5065)\end{array}$ & $\begin{array}{c}0.6543 \\
(0.5057)\end{array}$ & $\begin{array}{c}0.6032 \\
(0.5020)\end{array}$ & $\begin{array}{c}0.6359 \\
(0.5008)\end{array}$ & $\begin{array}{c}0.6449 \\
(0.4986)\end{array}$ & $\begin{array}{c}0.6671 \\
(0.4954)\end{array}$ & $\begin{array}{c}0.1343 \\
(0.4955)\end{array}$ & $\begin{array}{c}0.0792 \\
(0.4911)\end{array}$ & $\begin{array}{c}0.0966 \\
(0.4917)\end{array}$ & $\begin{array}{c}0.1550 \\
(0.4976)\end{array}$ \\
\hline Log-likelihood Ratio & $-326.70^{* * *}$ & $-324.72 * * *$ & $-326.98 * * *$ & $-325.86 * * *$ & $-325.14 * * *$ & $-322.93 * * *$ & $327.52 * * *$ & $328.21 * * *$ & $327.20^{* * *}$ & $328.52 * * *$ \\
\hline
\end{tabular}

atandard error in parentheses

$+\mathrm{p}<0.10$ * $^{*} \mathrm{p}<0.05$; $^{* *} \mathrm{p}<0.01$; *** $\mathrm{p}<0.001$

- One-tailed t-test for hypothesized relations 
Table 4: Partial Likelihood Estimates for Hazard of Partner Buyout

\begin{tabular}{|c|c|c|c|c|c|}
\hline Variable Name & (1) & (2) & (3) & (4) & (5) \\
\hline $\begin{array}{l}\text { Cultural Distance - Partner } \\
\text { Differences in PD }\end{array}$ & $\begin{array}{l}-0.4271 \\
(0.6234)^{\mathrm{a}}\end{array}$ & & & & \\
\hline $\begin{array}{l}\text { Cultural Distance - Partner } \\
\text { Differences in UA }\end{array}$ & & $\begin{array}{l}-1.3022 \\
(0.7499)\end{array}$ & & & \\
\hline $\begin{array}{l}\text { Cultural Distance - Partner } \\
\text { Differences in Individuality }\end{array}$ & & & $\begin{array}{l}-0.1099 \\
(0.8065)\end{array}$ & & \\
\hline $\begin{array}{l}\text { Cultural Distance - Partner } \\
\text { Differences in Masculinity }\end{array}$ & & & & $\begin{array}{l}-0.5841 \\
(0.5007)\end{array}$ & \\
\hline $\begin{array}{l}\text { Cultural Distance - Partner } \\
\text { Differences in (PD + UA) }\end{array}$ & & & & & $\begin{array}{l}-0.4084 \\
(0.3592)\end{array}$ \\
\hline Power Distance & $\begin{array}{l}-0.0594 \\
(0.0251)\end{array}$ & $\begin{array}{l}-0.0531 * \\
(0.0252)\end{array}$ & $\begin{array}{l}-0.0323 \\
(0.0305)\end{array}$ & $\begin{array}{l}-0.0404 \\
(0.0263)\end{array}$ & $\begin{array}{l}-0.0647^{*} \\
(0.0269)\end{array}$ \\
\hline Differences in $\mathrm{PD} * \mathrm{PD}$ & $\begin{array}{l}0.0201 * \\
(0.0116)\end{array}$ & & & & \\
\hline Differences in UA * PD & & $\begin{array}{l}0.0295 * \\
(0.0137)\end{array}$ & & & \\
\hline Differences in Individuality ${ }^{*} \mathrm{PD}$ & & & $\begin{array}{l}0.0042 \\
(0.0157)\end{array}$ & & \\
\hline Differences in Masculinity * PD & & & & $\begin{array}{l}0.0183 \bullet \\
(0.0145)\end{array}$ & \\
\hline Differences in $(\mathrm{PD}+\mathrm{UA}) * \mathrm{PD}$ & & & & & $\begin{array}{l}0.0127 * \\
(0.0064)\end{array}$ \\
\hline Exogenous Uncertainty & $\begin{array}{l}-1.9168 \\
(2.2621)\end{array}$ & $\begin{array}{l}-1.6697 \\
(2.2915)\end{array}$ & $\begin{array}{l}-2.2012 \\
(2.2884)\end{array}$ & $\begin{array}{l}-2.0129 \\
(2.3173)\end{array}$ & $\begin{array}{l}-1.7917 \\
(2.2811)\end{array}$ \\
\hline Subfield Value & $\begin{array}{l}-0.1443 \\
(0.2066)\end{array}$ & $\begin{array}{l}-0.0984 \\
(0.2014)\end{array}$ & $\begin{array}{l}-0.0560 \\
(0.1964)\end{array}$ & $\begin{array}{l}-0.0664) \\
(0.1960)\end{array}$ & $\begin{array}{l}-0.1110 \\
(0.2019)\end{array}$ \\
\hline Subfield R\&D Expense & $\begin{array}{l}-0.0195 \\
(0.0173)\end{array}$ & $\begin{array}{l}-0.0204 \\
(0.0174)\end{array}$ & $\begin{array}{l}-0.0140 \\
(0.0169)\end{array}$ & $\begin{array}{l}-0.0143 \\
(0.0170)\end{array}$ & $\begin{array}{l}-0.0212 \\
(0.0175)\end{array}$ \\
\hline Target Firm's \# of Partners & $\begin{array}{l}-0.3839^{*} \\
(0.1659)\end{array}$ & $\begin{array}{l}-0.3882 * \\
(0.1635)\end{array}$ & $\begin{array}{l}-0.4597 * * \\
(0.1659)\end{array}$ & $\begin{array}{l}-0.4460^{* *} \\
(0.1641)\end{array}$ & $\begin{array}{l}-0.3734 * \\
(0.1652)\end{array}$ \\
\hline Joint Venture & $\begin{array}{c}0.5012 \\
(0.5013)\end{array}$ & $\begin{array}{c}0.5850 \\
(0.5028)\end{array}$ & $\begin{array}{c}0.6206 \\
(0.5059)\end{array}$ & $\begin{array}{c}0.6045 \\
(0.5009)\end{array}$ & $\begin{array}{c}0.5825 \\
(0.4993)\end{array}$ \\
\hline Log-likelihood Ratio & $-323.94 * * *$ & $-324.71 * * *$ & $-327.43 * * *$ & $-326.88 * * *$ & $-324.14 * * *$ \\
\hline
\end{tabular}

- Standard error in parentheses

$\dagger \mathrm{p}<0.10 ;{ }^{*} \mathrm{p}<0.05 ;{ }^{* *} \mathrm{p}<0.01$; *** $\mathrm{p}<0.001$

- One-tailed t-test for hypothesized relations 
Table 5: Countries in Sample Located by Power Distance and Uncertainty Avoidance*

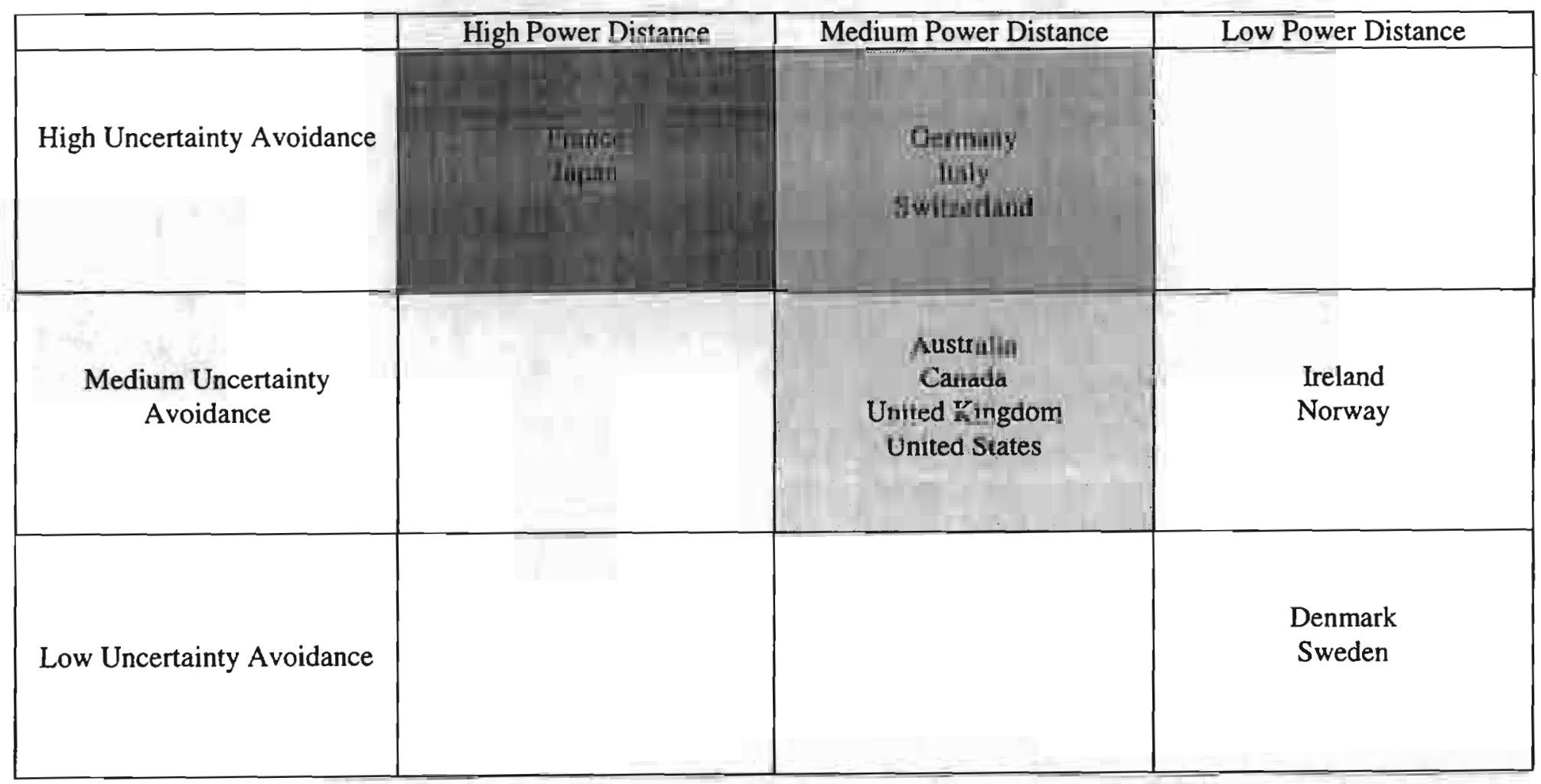

* The darker the background the more likely firms from these countries are to buy out their partners. 
No. 93-101 Gordon M. Philjips, and Robert J. Weiner

"Information and Normal Backwardation as Determithants of Trading Performance: Evidence from the North-Sea Oil Forward Market" 1994. The Economic Journal.

No. 93-102 Stephen R. Goldberg and Frank L. Hellin

"The Association Between the Level of International Diversification and Risk."

No. 93-103 John A. Carison

"Risk Aversion, Foreign Exchange Speculation and Gambler's Ruịn."

No. 93-104 John A. Carlson, Aasim M. Husain, and Jeffrey A. Zimmerman

"Penalties and Exclusion in the Rescheduling and Forgiveness of International Loans."

No. 93-105 Kent D. Miller

"Industry and Country Effects on Manager's Perceptions of Environmental Uncertainties."

1993. Journal of International Business Studies, 24: 693-714.

No. 93-106 Stephen R. Goldberg and Joseph H. Godwin

"Foreign Currency Translation Under Two Cases-Integrated and Isolated Economies."

No. 93-107 Kent D. Miller

"A Comparison of Managers' Unceriainty Perceptions and Country Risk Indices."

No. 93-108 Jon D. Haveman

"The Effect of Trade Indaced Displacement on Unemployment and Wages."

No. 93-109 Jon D. Haveman

"Sone Welfare Effects of Dynamic Customs Union Formation."

No. 93-110 John A. Carlson and Insook Kim

"Central Banks' Expected Profits From Intervention."

No. 94-001 Casper G. De Vries, Phillip A. Stork, and Kees G. Koedijk

"Between Realignments and Intervention: The Belgian Franc in the European Monetary System."

No. 94-002 Casper G. de Vries and K. U. Leuven

"Stylized Facts of Nominal Exchange Rare Returns."

No. 94-003 Kent D. Miller

"Operational Flexibility Responses to Environmental Uncertainties."

No. 94-004 Kent D. Milker

"Economic Exposure and Integrated Risk Management."

No. 94-005 Kent D. Miller

"Diversffication Responses to Environmental Uncertainties."

No. 94-006 John M. Hannon, Ing-Chung Huang, and Bih-Shiaw Jaw "International Human Resource Strategy and Its Determinants: The Case of Multinationals and Their Subsidiaries in Taiwan." 
No. 94-007 John M. Hannon, Ing-Chung Huang, and Bih-Shiaw Jaw

"International Human Resource Strategy and Control: The Case of Multinationals and Their Subsidiaries."

No. 94-008 ' John M. Hansion and Yoko Sano

"Customer-Driven Human Resource Policies and Practices in Japan."

No. 94-009 John A. Carlson and Insook Kinı

"Leaning Against the Wind: Do Central Banks Necessarily Lose?"

No. 94-010 John A. Carlson and David W. Schodt

"Beyond the Lecture: Case Teaching and the Learning of Economic Theory."

No. 94-011 Alok R. Chaturvedi, Hemant K. Jain, and Derek L. Nazareth

"Key Information Systems Management Issues in Developing Countries: Differences in the Indian and US Contexis."

No. 94-012 Jon Haveman,

"The Infuence of Changing Trade Patterns on Displacements of Labor."

No. 94-013 Stephen Goldberg, Charles A. Tritschler, and Joseph H. Godwin

"Financial Reporting for Foreign Exchange Derivatives."

No. 94-014 Charles Noussair, Charles Plott, and Raymond Riezman

"Una investigacion experimental sobre la estructura del comercia intemcional (Spanish Yersion)."

Translated: "An Experimental Investigation About the Structure of International Commerce."

No. 94-015 Marie Thursby and Richard Jensen

"Patent Races, Product Standards, and International Competition."

No. 94-016 Kent D. Miller and Jeftrey J. Reuer

"Firm Strategy and Economic Exposure to Foreign Exchange Rate Movements."

No. 94-017 John Hannon and Yoko Sano

"The Determinants of Corporate Attractiveness in Japan."

No. 94-018 John Hannon, Ing-Chung Huang, and Cheng-Chen Lin

"The Mediating Effect of Pre/Post Assignment Acitivities on the Quality of Work Life of Expatriates:

Evidence for Managers in the P.R.C."

No. 94-019 John Hannon, Ing-Chung Huang, and Cheng-Chen Lin

"The Mediating Effects of Organization Commilment and Job Involvement on the Relationship Between Quality of Work Life and Customer Service Attitudes."

No. 94-020 John A. Carlson and Marc Surchat

"A Model for Fiher-Rule Gains in Foreign Exchange Markets."

No. 94-021 Ch.N. Noussair, Ch.R. Plott, and R. Riezman

"The Principles of Exchange Rate Determination in an International Finance Experiment"

No. 94-022 Stephen R. Goldberg, Joseph H. Godwin, Myung-Sun Kim, and Charles A. Tritschler

"On The Determinants of Corporate Hedging With Financial Derivatives."

No. 95-001 Timothy B. Folta

"Sovereignty Conditions and Governance Modes: An Option Theory Approach"

No, 95-002 John A. Carlson and Dong-Geun Han

"Monetary Coordination, Fixed Exchange Rates and Noisy Markets." 
No. $95-003$

No. 95-004

No. 95-005

No. 95-006

No. 95-007

No. $96-001$

No. $96-002$

No. 96-003

No, 96-004

No. 96-005

No, 96-006

No. 96-007

No. 96-008

No. 96-009

No. $96-010$

No. 96-011

No. 96-012

No. 96-013
Jon D. Haveman

"Can Barriers to Trade Make a Differential?"

Kent D. Miller and Jeffrey J. Reuer

"Asymmetric Corporate Exposures to Foreign Exchange Rates."

Gerald J. Lynch and Bradley T. Ewing

"Money Growth Variability and the Term Structure of Interest Rates in Japan."

Nicholas C. Petruzzì and Maqbool Dada

"Inventory and Pricing in Global Operations: Learning from Observed Demand."

Kala Krishna and Marie Thursby

"Whilher Flat Panel Displays""

Thomas Brush, Catherine Maritan, and Aneel Karnani

"Managing a Network of Plants Within Multinational Firmts."

John J. MeConnell, Heidi J. Dybevik, David Haushalter, and Erik Lie

"A Survey on Domestic and International Stock Exchange Listings with Implications for Markets and Managers."

Kala Krishna, Suddhasatwa Roy, and Marie Thursby

"Implementing Market Access."

Jon Haveman, David Hammels

"Trade Creation and Trade Diversion: New Empirical Results."

Riki Takeuchi, John $M$. Hannon

"Antecedents of Expatriate Spouse Adjustments: An Analysis of Japanese Spouses in the Untited States."

Bih-Shiaw Jaw, John M. Hannon

"Determinants of International and Intercultural Human Resource Control: The Case Of Taiwanese Subsidiaries in the People's Republic of China."

John M. Hannon, Riki Takeuchi

"Adjustment and Job Satisfaction as Antecedents of Intent to Stay: The Case of Japanese Expatriates in the United States."

John M. Hannon

"Using International Human Resource Management to Inform the Business Intelligence Function."

Jefrey J. Reuer, Kent D. Miller

"Agency Costs and the Performance Inplications of International Joint Venture Internalization."

Neven Valev

"International Lending by U.S. Banks."

Kala Krishna, Marie Thursby, and Suddhasatwa Roy

"Implementing Market Access." (revised)

Jon D. Haveman

"The Effect of Trade Induced Displacement on Unemployment and Wages."

Robert A. Buckle and John A. Carlson

"Inflation and Asymmetric Price Adjustment." 
No. 97-00I Jeffrey J. Reuer

"Shareholder Wealch Effects of Joint Venture Termination: A Transaction Cost Analysis."

No. 97-002 Jon Haveman and David Hummels

"What Can We Learn from Bilateral Trade? Gravity and Beyond."

No. 97-003 Douglas Bowman, John U. Farley, and David C. Schmittlein

"Cross-National Empirical Generalization of a Supplier Selection and Usage Model for Foreign

Exchange Services."

No. 97-004 Kent D. Miller

"Measurement of Perceived Environmental Uncertainties: Response and Extension."

No. 97-005 John A. Carlson, C. O. Osler

"Rational Speculators and Exchange Rate Volatility."

No. 97-006 Marie Thursby, Kala Krishna, and Suddhasatwa Roy

"Procompetitive Market Access," Forthcoming, Business and Economics for the $21^{\text {st }}$ Century, Vol. 1.

No. 97-007 John A. Carlson

"Currency Boards, Expectations and Inflation Persistence."

No. 97-008 Jon Haveman, Usha C. Nair, and Jerry G. Thursby

"The Effects of Protection on the Pattern of Trade: A Disaggregated Analysis," Forthcoming, Business

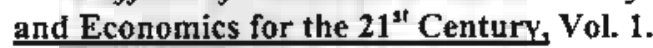

No.97-009 George Horwich

"Economic Lessons of the Kobe Earthquake."

No. 98-001 John J. MeConnell, Kenneth A. Carow, and Gayle R. Erwin

"Financing Publicly Traded U.S. Corporations in Public and Private Security Markets, 1970-1997;

Where, How, How Much, Wilh What, When, and Why."

No. 98-002 Timothy N. Cason, Tatsuyoshi Saijo, and Takehiko Yamato

"Voluntary Participation and Spite in Public Good Provision Experiments: An International

Comparison."

No. 98-003 Jon D. Haveman, Janet S. Netz, and Vivian Lei

"International Integration and Growth: A Survey and Empirical Investigation."

No. 98-004 Keith V. Smith, Nabil T. Khoury, and Peter I. MacKay

"Comparing Working Capital Practices in Canada, the United States, and Australia: A Note."

No. 98-605 John A. Carlson and Neven T. Valev

"Expectations Formation and Inflation Persistence."

No. 98-006 John A. Carlson and Carol L. Osler

"Determinants of Currency Risk Premiums."

No. 98-007 Jon D. Haveman, Usha Nair-Reichert, and Jerry Thursby

"Trade Reduction, Diversion and Compression: Empirical Regularities in the Effect of Protective Measures."

No. 98-008 Kale Krishna, Suddhasatwa Roy, and Marie Thursby

"Can Subsidies for MARs be Procompetitive?"

No. 99-001 Gabriele Camera and Johannes Winkler

"Stores, Prices and Currency Substitution" 
No. 99-002 John A. Carlson and Neven T. Valev

"Sources of Dispersion in Inflation Forecasts"

No. 99-003 Timothy N. Cason, Tatsuyoshi Sajjo and Takehiko Yamato

"Voluntary Participation and Spite in Public Good Provision Experiments: An International Comparison"

No. 99-004 Jay Dahya, John J. McConnel] and Nickolaos G. Travlos

"The Cadbury Committee, Corporate Performance and Top Management Turnover"

No. 99-005 David J. Denis, Diane K. Denis and Keven Yost

"Global Diversification, Industrial Diversification and Firm Value"

No. 99-006 Timothy B. Folta and Walter J. Ferrier

"The Effect of National Culture on Partner Buyouts in Cross-Border Biotechnology Alliances"

No. 99-007 Jon D. Haveman and Jerry G. Thursby

"The Impact of Tariff and Non-Tariff Barriers to Trade in Agricultural Commodities:

A Disaggregated Approach"

No. 99-008 Huseyin Gulen and Stewart Mayhew

"Stock Index Futures Trading and Volatility in International Equity Markets"

No. 99-009

Stefan Lutz and Alessandro Turrini

"Skilss, Labour Costs and Vertically Differentiated Industries: A General Equilibrium AnaIysis"

No. 99-010 Michael Watts and Alexander Kovzik

"Reforming Undergraduate Economics Instruction in the Former Soviet Union" 


\section{The Effect of National Culture on Partner Buyouts} in Cross-Border Biotechnology Aliances

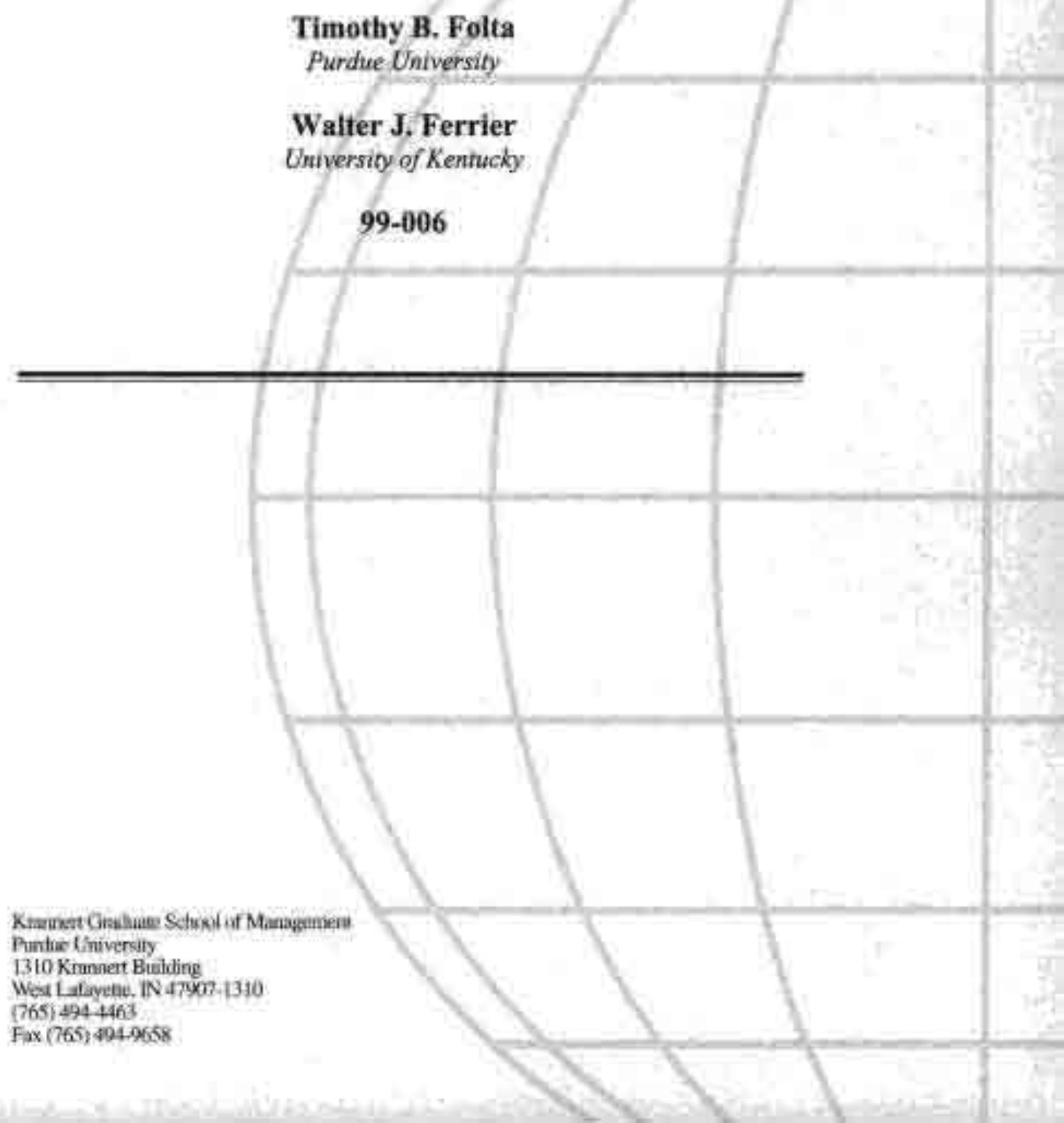




\title{
THE EFFECT OF NATIONAL CULTURE ON PARTNER BUYOUTS IN CROSS-BORDER BIOTECHNOLOGY ALJIANCES
}

\author{
TIMOTHY B. FOLTA \\ Krannert Graduate School of Management \\ Purdue University \\ West Lafayette, IN $47907-1310$ \\ (765) $494-9252$ \\ fax: (765) 494.9658 \\ E-mail: foitat@mgmt.purdue.edu \\ WALTER J, FERRIER \\ Gatton College of Business and Economics: \\ University of Kentucky \\ Lexington, KY 40506-0034 \\ (606) $257-9326$ \\ fax: (606) 257-3577 \\ E-mail: wallyi@pop.uky.edu
}

December 8, 1999

Sortheming in

Revised manuscripf submed toumat of High Technojogy Management Reseatch

We are grateful to Bob Dahistrom, Andrew inkpen; and two anconymous reviewers for helpfut commients on an earliet version of this paper, and to Kent Miller for his help on a related project. An earlier version of this papet appeared in the 1997 Academy of Management Best Paper Proceedings. 


\title{
THE EFFECT OF NATIONAL. CULTURE ON PARTNER BUYOUTS IN Cross-BORdER BIOTECHNOLOGY ALLLIANCES
}

\begin{abstract}
Aвsthact
This stidy examines how national culture influences the likelithood and rate of buyouts among $R \& D$ equity alliances and joint ventures in the biotechnology industry. We bypothesize that the interaction of specific national culture attributes and cultural differences between alliance partners bear upon: a) the amount of endogenous uncertainty surrounding the potential integration of the target firm and b) the marginal rate of leaming in thierarchical versus collaborative govemance. Applying a competing hazard model to a sample of 173 joint ventures and minority equity coltaborations in the biotechnology industry, we found that investiag firms from high power distance and high uncertainty avoidance countries are more likely to buy out their alliance partners. Furthermore, greater cultural distance between alliance partners increases the likelihood of partner buyout when investing firms are from high power distance countries.
\end{abstract}


As knowledge intensive industries become increasingly global, heh tech firmis are cunfronted with the strategic chatlenges, opportutities, and risks asuociated with cross-horder alliances. Indecd, considerable managerial and scholariy attention has been paid to not only the benefits, of such aldiafees, but also on the esinsactional difficulties wrough by aliance parters, from different sational euttures. However, most of these efforts have focused on the choice of inital govenatice mode (c.g., Enamilli, 1996, Kogut \& Singh, 1988; Shane, 1993). The present study is motivated in three respects. Firht, it is beconing clear that governarice decisions maly invol ve at stratery to equentially invest ecoity in an sllianter partnet over ume (Chang, 1995; Penner-Hahn, 1998), Second, partnerships often tenminate witb acguisition (Folta, 1998; Hurity, Kogut. 1991; Muller d Bowman, 1992) as opposed to other forms of termination, such as dissoletion or thirt party buyouts. Third, hitte research to date has explicitly examined whether national culture chanacteristics influence pantems of sequemtial investment and the particulas mode of alliance termination.

This paper is an atsenpt to fill the gaps noted above by examinirg the role of nationa] culture on the Jikeliboud and rate of buyous among R\&D equily alliances and joint ventures in the biotechnology indus.ry. Finner buyouts are a relatively common occutrence in what kubwledge-intensive industries. Fot exaruple, Palk and Russo (1996) found that 16.2 percent of joint ventures in the electroaics industry were acequired within three years of founding, while Cho (1991) tis" found that 13.6 percent of minonity investments ended in acquistions withis one year of initiation. 'Yet, despite their frequency, very few studies have expliclaly treated partuer bujouts as a distinct form of parnership termination. This is unfonunate because Park and Russo (1996) and Park and Unpson (1997) argue that termination by acquisition and temination by dissolution may be driven by entiriy different factors. 
Like our study, Kogut (1991) examined the parner buyout decision through an option theory jens. Whereas his sudy examines the role of exogenous tactors on buyouts, aut focis is an endogenous uncertainty and the impact of national culture. To date, only Park and Ungson (1997) have examined the role of national culture on the partner bayout decision. They reveal some cvidence that cultural distance increases the likelihood of buyout of the joint venture, even after controling for other important factors such as oryatizational and operational differences betweet partners, the type of transaction, and the incidence of prior transactions between partnen. Unfortunately, since their focus was ternination by dissolution, they do not develop any a priori theoretical arguments about the determinants of buyouts. Neither do thcy offer any empirical evidence regarding the effects of dimensions of culture other than eultural distance.

There are other masons to believe that bational culture may play an impontant roie in the partuer buyour decision. Chumg (1995) and Hunty et al, (1992) found that senguential investment patierns were found to Liffer across U.S. and Japunese venture cayital [rms. Relative to U.S. firns, Japarasese firms exhibit incremental approacles to expansiot. Subsequent to news inticating venture success, Japanese venture capital firms tended to upgrade a venture investinen to a joint venture or acquisition, while U.S. firms tended to self their ownership stake. Chang (1995) questions whether the sequential investment pattern holds for westem firms, reasoning that culturat and institutional background of non-western firm favor an incremental and evolutionary approach to investment. Although he does not test this proposition, be encourages study of the matter.

Hofstede (1980) deflined national culture as the collective programming of the haman mind. His dimensions of eulture are well known and include uncertainty avoldance, power distance, masculinity-femininity, anif individualism asul vary considerably across countries. 
Understanding which cultural dimensions bear upon the decision to buy out a partner may shed light on several important issues. For instance, investing firms in knowledge-intensive industries would benefit from knowing how target firms from different eultures tend to respond to sequential investment behavior by partners. This ex ante knowledge may prove helpful in negotiating the terms of R\&D equity collaborations. Similarly, collaborating firms would be advised to understand whether foreign partners are likely to consider thern an acquisition candidate. At a broader level, national culture may have significant implications for understanding the fevel and type of commitment firms make in emerging, high tech industries.

We explicitly examine the effects of national culture on the rate of partner buyout across twelve different countries. Out hypotheses are developed using aggregate measures of cultural distance by Hofstede (1980) and Ronen and Shenkar (1985), as well as more specific dimensions of culture relating to the investing firm. Esing a time varying model, we test these hypotheses on a sample of minority investments and joint ventures in the biotectsnology industry. In the past two decades, the biotechnology industry has grown explosively, largely due to the recognition that biotechnology could disrupt old markets, ereate new products, and cheapen current manufacturing process. Virtually every developed country thas targeted leadership in biotechnology as a natisnal goal (Office of Techinolegy Assessment, 1991).

\section{BACKGROUNB}

Following Kogat (199)), we characterize R\&D equity collaborations as a rwo-stage compound option; whereby investing firms holding a limited equity stake in a target firm can track knowledge development and (market and technological) opportunities in industries. Such equity collaborations allow firms to maintain strategic flexihility to respond to industry trends 
that are difficult to predict. Following the initial equity investment, exercise of the first stage of the option is represented by the full acquisition of a target partner. In the case of R\&D partnerships where an investing firm has taken a minority equity stake, partner buyout refers to the acquistion of the R\&D supplier/partner. Partner buyout for joint ventures refers to the acguisition of the joint venture by one of the parents. ${ }^{2}$ Exercise of the second stage growth option is represented by making further discretionary investments in research or commercial opportunities resulting from the first stage commitment. In this view, equity collaborations may be initiated as a way to manage endogenous and exogenous uncertainty. Exogenous and endogenous uncertainty have different eftects on the decision to commit additional capital (Dixit \& Pindycki, 1994; Rivoli \& Salorio, 1996).

Exogenous uncertainity cannot be reduced by the actions of the firm. In the case of emerging. technology industries, exogenous uncertainty exists when, for exarnple, the technological trajectory of the industry is indeterminate, industry infrastructure is lacking, and/or when key Jegislation affecting the industry is pending. Given these conditions, the premature acquisition of firms deveioping emerging technologies may impose considerable risks because the investing firm gives up the option of waiting for new information that might affect the desirability or timing of the investment. The ability to delay irreversible investment expenditures until exogenous uncertainty is resolved can be an important source of flexibility in a project and profoundly affect subsequent decisions to invest (McDonald \& Siegel, 1986),

By contrast, endogenous uncertainty can be decreased by actions of the firm. Potential 3ources of endogenous uncertainty for the investing firm include: expansion into unfamiliar international markets, integration of firms from diverse cultures, initiation of $R \& D$ projects that take time to develop, or inability to assess the target firm's knowledge. This form of uncertainty 
is primarily resolved by learning; that is, actually performing the activities associated with a given project. Previous research suggests that greater endogenous uncertainty increases the value of information and thus, increases incentives to invest in knowledge generatiou or acquisition (MeCardle, 1985). In the presence of endogenous uncertainty, the key characteristic that makes the investment in knowiedge so attractive is the ability to temporarily or pernaniently suspend further equity investment if the expected value of the completed projects declines due to exogenous shocks. Roberts and Weitzman (1981) have shown that if learning is enhianced by moving to the next stage of the project, there is an incentive to speed up the rate of commitment.

We argue that it is the combination of endogenous tuncertainty and enhanced learning by moving to the next stage that motivates the decision to commit incrementally. This staged investment approach takes on value when internalizing the partner increases the rate of learning about the project In this sense, exereising the buyout of a partier is comparable to the exercise of a call option on equities that pay dividends. In the presence of dividends (that come in the form of learning udvantages) there may be an incentive lo exercise the parther buyout option early. If the target turns out to have skills that are relevant for the partner but cannor be easily transferred across fittn boundaries after a brief interchange, $u$ buyout may be the only viable alternatives. Relative to arm's-length contracts, internalization faciltates transfer of technological capabilities because the acquirer can tap into its repository of social knowledge that structures cooperative action. According to Kogut and Zander (1992), this difference in the marginal efficiency of technology transfer constitutes the ownership advantage of the firm. ${ }^{3}$ Internalizing the pautner firm may increase the efficiency of knowledge transfer, thus enabling the firm to reduce future $R \& D$ costs so that growth opportunities can be exercised at a lower cost. 
In sum, there are at least three important factors which need consideration when examining determinants of partner buyouts: (1) the level of exogenous uncertainty, (2) the level of endogenous uncertainty, and (3) the relative rate of learning inside versus outside firm bouncaries. Unless endogenous uncentainty (2) is present, the relative rate of learning inside versus outside the firm (3) will have no consequence. This implies an interaction effect. In this paper, we focus explicitly on the expected interaction between endogenous uncertainty and learning. In the presence of endogenous uncertainty firms will invest sequentialiy when such commitment yields information about future opportunities. Firms that learn more efficiently in: hierarchies are candidates to buy out their partners:

In the next section we describe our main thesis: that national culture traits and cultural differences between partners should contribute to endogenous uncertainty and rates of learning in bierarchy, and therefore, should bear upon the buyout decision.

\section{HYPOTHESES}

When valuable, but unexplored technology is resident in a target firm, investing firms differ in terms of how learning activities are to be organized. Consistent with previous research (e.8., Adlet, 1991; Hofstede, 1991; Olie, 1994; Osbom \& Hagedoorn, 1997, Powell, Koput \& SmithDoerr, 1996), we argue that the cultural atributes of among investing firms are principal. deternunants of thow firms choose to organize learning activities. We motixate our hypotheses using two of Hofstede's (1980) dimensions of national culture: penver distance and uncertainfy avoidance. We believe that these two dimensions are the most relevant in the study of partner buyouts for several reasons. First, as noted by Hofstede, "Of the four dimensions of national culture, power distance and uncertainty avoidance in particular affect our thinking about. 
organizations, Organizing always demand the answering of (wo questions: (1) Who has the power to decide what'? And (2) What rules or procedures will be followed to attain the desired ends?" (1991:140)* In contrast, Hofstede believes that while his other two dimensions, masculinity and individualism, broadly reflect the values of the national culture, they imply little about administrative practices within organizations. Consistent with the importance placed on power distance and uncertainfy avoidance inside organizations, these two dimensions have been the most pervasive in research eximining the behaviors of mnltinational corporation as evidenced by the work of Erramilli (1996), Gatignon and Anderson (1988), Kogut and Singh (1988), and Shane (1993), Finally, Hofstede (1991) argues that various combinations of power distance and uncertainty avoidunce correspond directly to each of Mintaberg's (1983) preferred authority configurations and coordinating mechanisms, thereby capturing both national and organizational traits. It seems that power distance and uncertainty avoidance are the most distinctive culturat dimensions which influence orgamizational structure and functioning (Hoecklin, 1995).

We argue that power distance of a national culture will influence the degree to which the investing firm can feam in hierarchy. Also, uncertainty avoidance and culnutal distance are argued to contribute to endogenous ancertainty in the equity partnet relationship"

\section{Power Distance and Learning Inside versus Outside the Firm}

As noted, Kogut and Zander (1992) point to the important differences in learning efficiency across governance modes. They argue that it is more efficient to transfer complex knowledge within the houndaries of a firm because learning processes are a function of shared values and assumptions. If national culure embodies social knowledge and organizing principles, it 
therefore bears upon the expected efficiency of leaming subsequent to partner buyout. Firms from cenain cultures may learn more efficiently when internalized, while the marginal rate of learning in hierarchy may be lower for firms from other cultures. Hall (1976) argued that cultures vary greatly in the processing of information and patterns of cormmunication.

One cultural attribute that should influence the rate of learning in hierarchies relative to collaborations is power distance (PD). Power Distance is defined as the extent to which members of a society accept that power in instifutions and organizations is distributed unequally" (Hofstede, 1985: 348-349). As applied to organizations, control, decision making, and authority are likely to be highly centralized (Hofstede, 1980). Acquiring firms from cultures characterized as high PD operate most comfortably in hicrarchy. In such countries, we expect the marginal rate of learning or technology transfer to be highest in hierarchy. Indeed, Hofstede (1991) discusses the implications of culture in an important learning context - in schools. In high PD cultures, such as Japan, learning is structured and hierarchical. By contrast, learning is loose and mure unstructured in Jow PD cultures.

One mighi expect that firms from high PD cultures will move directly to outright acquisition, and avoid the first stage equity collaboration. Consistent with this expectation. Shane (1993) found that the highet the PD, the greater the likelihood of hierarchical control in transactions. More recently, Erramilli (1996) found that firms from countries with higher PD are inore likely to seck majority ownership in foreign subsidianes.

In the absence of endogenous uncertainty, firms from high PD cultures will acquire outright. However, in the presence of endogenous uncertainty, they will invest incrementally, beginning with the first stage equity collaboration. Several cultural atributes infiuence endogenous uncertainty, 


\section{Oncertainty Avoidance, Cultural Distance, and Endogenous Uncertainty}

The study of national culture on governance modes has predominantly focused on uansaction cost explanations, where the cultural atmibutes or partner differences in national culture are expected to moderate the ability of managers to perceive the potential fot opportunistic behavior by partners (Hartigan, 1985). As noted eartier, these transaction costs were found to be a key determinant for dissolution of equity partnerships and joint ventures and have been carefully articulated in the literature. Building on previous research, we argue that uncertainty awoidance (UA) and cultural distance (CD) are two important contributors to endogenous uncertainty.

Uncertainty avoidance (UA) is defined as the "degree to which the members of u saciety feel uncomfortable with uncertainty and ambiguity, which leads them to support beliefs promising certainty and to maintain isstitutions protecting conformity" (Hofstede, 1985: 348-349). In an organizational context, having high leveis of UA leads managers to make less nisky decisions and develop coping mechanisms to control uncertainty, such as developing complex systems of rules and regulations and following structured, ritual behavior (Hofstede, 1980).

Uncertainty avoidance was shown to be an importani predictor of foreign market entry modes. For instance, Kogut and Singh (1988) found that multinational corporations from callares high in UA are more fikely to choose joint ventures or greenfield entry modes over full acquisitions. These authors attribute this result to the fact that the umcertainty associated with integrating the management teams of both subsidiary and parent firms is untenable. Therefore, these firms are more comfortable with either a greenfield investment or establishing an equity partnership with the host county target. Shane (1993) found that firms from high UA societies favof licensing over acquisition-type entry modes. 
Given their proclivity toward risk avoidance, it is not surprising that firms from high UA cultures prefer staged investment to outright commitment. At the same time, we expect firms from high UA cultures to benefit from a transition toward hierarchy because of the added structure in place to control opportunistic behavior. When firms are from cultures that are also high in power distance, we expect there is added incentive to internalize the target fimt in order to learn about growth opportunities more efficiently: Our proposition that high $\mathrm{PD}$, high UA eultures are quicker to internalize appears consistent with arguments made by Hurry et al. (1992) and Chang (1995), who asserted that Japanese firms, relative to U.S. firms, were more likely to eventually acquire target firms. By contrast, U.S. firms are more likely to sell their equity positions in target firms foliowing the target firm's initial public offering Indeed, according to Hofstede (1980), the Japanese are ranked significantly higher on both PD and UA compared to the United States.

Hypothesis 1: When established fimus are from cultures ranked high in uncertainty avoidance and high in power distance, partner buyouts are more likely. In the pussage above, we argued that established firms from cultures with ligher power distance iearn more efficientiy from their partners, and that the marginal incentive to acquire their partners is highest when the relatiotship is confronted with endogenous uncettainty. While uncertainty avoidance is one dimension that accentuates endogenous uncertainiy, cultural distance (CD) between the partners may also influence the amount of endogenous uncertainty. Cultural distance is defined as the degree to which the home country eulture of an investing fim is dissimilar from that of the host country market and firms operating therein. When there is more cultural distance between partners, the ability to effectively observe and predict opportunism among partners is hindered (Kogut, 1988), leading to higher potential transaction 
costs. Here, transaction costs represent communicstion and control costs embodied in cultural differences.

A large body of work has focused on initial govemance choice and found cultural differences lead ñrms to shy away from hierarchy (Kogut and Singh, 1988; Gatignon and Anderson, 1988; Shane 1993). Other researchers have attended to the role of cultural distance on the stability of existing partnerships, finding that it contributes to a higher rate of partnership dissolution (Harrigan, 1985; Barkema, Bell, \& Penning5, 1996: Barkemu, Stienkar, Vermeulen, \& Bell, 1997: Park and Ungson, 1997). More relevant to our study, Olie (1994) and Elsass and Veiga (1994) argued that the blending of diverse cultures tends to be a challenging obstacie to successful mergers. Indeed, cultural differences between firms was found to predict stress. negative attitudes toward merger, and the lack of cooperation between firms subsequent to merger (Weber, Shenkar, \& Raveh, 1996).

These findings suggest that for existing partnerships, cultural differences raise the degree of endogenous uncertainty facing partnerships, and the endogenous uncertainty facing prospects for successful mergers of the firms. The successful transfer of knowledge among culturally distant partners is an indeterminate process. This view is captured clearly by Luostarinen, who defined cultural distance as "the sum of factors creating, on the one hand, a need for knowledge, and on the other hand, barriers to the knowlodge flow and hence also for flows between the home and the target countries" $(1980 ; 131-132)$.

Consistent with Hypothesis 1, we argue that when endogenous uncertainty is combined with more efficient learning in hieranchy (i.e, high PD), parner buyouts should ensue. As a result, when partiers are culturaliy distant and the investing firm is from a culture that is high in power 
distance, we expect there to be added incentive to internalize the target firm in order to leam about growth opportunities more efficiently.

Hypothesis 2: When partners are more culturally distant and the established firm is ranked high in power distance, partner buyouts are more likely.

\section{RESEARCH DESIGN}

\section{Sample}

We drew a sample of minority equity collaborations and joint ventures involving dedicated biotechnology firms (DBFs) from the North Carolina Blorechnology Center (NCBCIAcrions Database. This database includes detailed information regarding over 4,000 relationships and transactions among firms in the biotechnology industry since 1978. In particular, the NCBC dstabase includes the following transaction characteristics; a) whether the transaction involved an exchange of equity via a minority invesiment of a joint venture, b) the transaction date, c) the Fdentity and number of partners involved, if) the type of partners involved (i.e., DBF, established firm, government, or university), e) each party's home couniry, f) the tectunologicat subfield, and g) a general description of each transaction. All transactions were cross-validated with a similar database, Bioscan in the event that the transaction dates differed across sources, we used the earliet of the two dates.

In studying the NCBC Actions database and comparing with Bioscan we collected information on 618 equify collaborations. This original sample was reduced for three theoretical reasons. First, our compiled data were restricted to iransacnons involving only two parties, a target DBF domiciled in the United States and estahlished firms having core businesses outside of biotechnojogy. We believe it is easier to identify the integrated manufacturer as the holder of 
the call option to scquire, a belief consistent with Hurry et at. (1992). This is particutarly reasonable in cases where established firms take a minority equiry stake in a DBF. These cases constitute 83,8 percent of our final sample. Determining who holds the call option is more challenging in joint ventures, where both parties contribute captal and knowledge to a jointly awned und controlled entity. We control for likelihood that joint ventures may be bought out by the DBF by including a joint venture dummy variable and by modeling joint venture buycuts by the DBF firm as a competing event.

Second, we restricted our sample to include only four broad subfieids: a) therapeutics, b) diagnosties, e) agriculture (ag/toio), and d) supplier/speciatty chemical. These subfields account for a large majority of all firms dedicated to biotechnology (Dibner, 1992), This focus on the largest subfields was necessary beeause of cur need to have a critical mass of public firms to generate stock market indices for each subfield for our measure of exogenous uncertainty.

Firally, we focus on equity collaborations with DBFs dorniciled in the United States. This enabled us to better control for exegenous events specific to country boundaries. Given these constraints on our database we identified 248 equity collahorations initiated between 1978 and 1995. Of these, we were unable to obtain the precise starting dates of 30 transactions, despite supplementing our search using Lexis/Nexus and SEC Schedule 13D filings.

We made considerable effort to verify the outcome of each parnership. If the December 1995 issue of Bioscan listed the equity partnership as ongoing, the tansactioa was coded as nght-censored, Otherwise, a systematic search was undertaken to understand the nature of the transaction termination. NCBC and Bioscan data were supplemented with a search of Emst \& Young Biotechnology Industry Reports, Predicast's F\&S Index of Corporate Change. 
Lexis/Nexis, and SEC Schedule 13D filings. From this effort we were able to verify the timing and outcome of 173 equity partnerships constituting our final sample.

Of the 173 transactions in our final sample, 23 were terninated by partner buyout by established firms, 39 were dissolved, 21 were terminated by other means ( 6 joint ventures were acquired by the DBF parther, 5 joint ventures were acquired by third parties, 10 DBFs were acquired by a third party), and 90 were right censored; that is, they were still in effect at the end of $1995^{7}$ Tuble f provides a broikdown of the number of estublished firms from each country that have initiated equity collaborations with U.S. biotechnology firms. Here, we also list the outcome of these equity collaborations for each country. While equity investments are most prominentiy undertaken by firms in a few countries, there seems to be a clear difference in the outcomes of these collaborations. U.S fims have a high percentage of partnership dissolutions and third-party buyouts. Japanese firms and those from the United Kingdom have a significant proportion of partnerships maintained, as do firms from Switzerland, Germany, and Sweden. While these trends show clear differences in country propensities regarding equity collaboration outcomes, it is unclear whether these patterns are statistically robust when controlling for cultural factors, firm-specific factors, and those relating to the value and exogenous uncertainty regarding the lechnology. Furthermone, Table 1 does not consider the timing of the outcome event. For exampite, while it is clear that a greater percentage of Japanese fims maintained their equity stake than do U.S. firms, it does not help us understand whether Japanese firms maintained their equity retationships fonger than U.S firms.

Insert Table I about here 


\section{Model and Method}

We selected a competing-risk, discrete-time event history analysis to test our hypotheses. Event history models are especially appropriate for analyzing longitudinal data when the dependent variable is a discrete event and the timing of the cvent's occurrence is of particular interest. Competing risk is a special form of event history analysis that is used when the dependent variable has two or more outcomes and the occurence of any one outcome removes the subject from the risk of the other outcome(s). Buyouts are one of several ways in which 3 partnership may be terminated Other forms of termination include (a) dissolution of the partnership, (b) acquisition of a biotechnology firm or joint venture by a third party, and (c) acquisition of a joint venture by the biotechnology partuer (rather that acquisition by the established firm). Although we do not develop explicit hypotheses regarding these other forms of termination, they do represent relevant "competing bazards" in that they preclude-subsequent occurrences of partner buyouts. To model the competing hazards, the hazand rate function is defined as.

$$
\text { (1) } \quad h_{j}(t)=\lim _{t \rightarrow 0} F_{j}(t, t+s) / s
$$

where $h(t)$ is the hazand function associated with either parther buyout $(j=1)$, partnership dissolution $(j=2)$, or other termination $(j=3), P(t, t+s)$ is the probability that event type $)$ occurs in the interval between $t$ and $t+s$, given that the partnership is at risk at time $t$.

Cox's (1975) partial likelihood method for parameter estimation allows us to incorporate time dependence into the model, without specifying its form. The general form for the Cox proportional hazards models estimated in this study is:

$$
\log h_{j}(t)=a_{i}(t)+\beta_{j} X(t)+\lambda_{j} Y
$$


where $a,(t)$ may be any function of time, $X(t)$ and $Y$ are vectots of time dependent and time invariant explanatory variables, and $\beta_{1}$ and $\lambda_{\text {y }}$ are vectors of estimable parameters. We used TDA version 5.7 to simultaneously estimate the competing bazands model (Rohwer, 1994) with Cox's partial likelihood method. We do not provide estimates for the baseline hazard function, $a_{j}(t)$. since partial likelihood estimation discards this function.

The three events - buyoul, dissolution; and other termination - were updated monthly. The sample includes 9,843 monthly periods. The cultural variables wero not time varying, but many control variables were updated monthly.

\section{Culture Variables}

Hypothesis I is tested by multiplying Hofstede's (1980) well-known measures of uncertainty avoidance and power distance to each country in our sample. Hypothesis 2 also suggests a multiplucutive function involving power distance and cultural distance. Our test considers two alternative measures of cuttural distance. First, following Kogut and Singh (1988). we measured Hofstede's cuitural distance (HCD) as a composite index based on the each of the four cultural dimensions identified by Hofstede (1980).

We also ased a second measure of cultural distance is generated from a stady by Ronen and Shenkar (1985), who synthesized country clusters into tine groupings of countries with similar work-related attitudes and values. The "Anglo" cluster involves Australia, Canada, Irelarid, New Zealand, South Africa, United Kingdom, and United States. All other countries in the study were grouped inte the other eight clusters. Using this data, we constructed a measure of cultural distance such that when the established firm fell in the Anglo cluster, Ronen's cultural distance (RSCD) was coded " $0 "$, otherwise it was coded " $1 "$ ". 


\section{Control Variables}

Clearly, cultural factors may not dominate partnet buyout decisions. We argued earlier that exogenous forces partially dictate how uncertain future payofis are and whether a buyout optson Is in-the-money. Other forces specific to the industry, the investing firm, and partner relationship may also bear upon the buyout decision, In this section, we describe our attempts to control for the factors found to be important by preyious researchers.

Kogut (1991) argued that exogenous forces determine whether a buyout option is in-themoney, He argued that whea industry sales deviated positively from industry forecasts, join venture partners wouid seek to acquire the joint venture. His anntal measures, shipment growth and deviation from expected growth, are meant to capture the certainty to which joint ventures operating in an industry have appreciated in value. Our measures of exogenous variables are in the same spitit, but are measured differently. Whereas Kogut's study spanned several industries and uses annual measures, ours concentrates only on biotechnology, and we consequently focus an measuring exogenous forces within technological subfields on a monthly basis. Sales measures are unreasonable in this industry because most firms have no revenues from sales. Like Folta (1998), we measure subfield value and suhfield (exogenous) uncertainty using stock markel indices generated from publicly traded furm in concentrating in particulat biotechnology subfields. These measures were consiracted from stock prices that were gathered from the Center fot Research in Security Prices data base, and are described briefly below, but in more detail in Folta (1998).

Differences in the expected value of growth opportumities across the four subfields (Therapeutic, Diagnostic; Ag/Bio, and Supplier / Specialty Chemical) with four stock indices that were created from weekly returns of nine U.S. biotechnology firms specializing in the respective 
subfieids. The subfield value of firm $\mathrm{j}$ was measured as the value of the monthly biotechnology index for subfield $m$ (when $/ \in m$ ). These indices are weighted equally. Weekly values of the indices were then averaged within each month to get monthly index values for each of the four subfields. Subfield value was transformed by taking its natural logarithm to correct for positive skewness,

Exogenous unceriainty was measured as the 26-week standard deviation of the log of weekly retums for each of the four biotechnology subfield indices. The 26-week measure was thosen because if provides enough history to produce a reliable measure of volatility, without assuming constant variance over a longer period of time. Exogenous uncentainty was converted to a monthly measure by averaging the weekly standard deviations within any given month.

Substantial literature has confirmed the importance of industry structure on the choice of governance mode. We use average subfield R\&D expenditures divided by average total expenses to control for such effects. Comventionally, the relationship of R\&D expense is said to encourage integrative modes, such as acquisition, th order to provide adequate administrative control for coping with higher degrees of luman and dedicated capital specific to a transaction. Using this logic, we might expect a positive relationship between R\&D expense and partner buryout.

Park and Ungson (1997) did not control for exogenous forces, but did find that a series of dammy variables related to the partnership influenced the buyout decision. They found that partners with the same SIC code were less likely to acquire their partners, partners having a prior relationship were more likely to end in acquisition, partnerships involving technology transfer were less likely to end in acquisition, and partnerships involving multiple products were more likely to end in acquisition. We test for some of these same effects, but not all. By derinituon, 
our sample includes partners from different SIC eodes and partnerships involving technology transfer.

Park and Ungson (1997) have highlighted the important moderating role that prior relationships have on the effect of cultural differences on parnership dissolution. While they did not lest for whether this same effect holds for partner buyouts, it may be reasonable to expect prior relationshups to moderate either the degree of endogenous uncertainty or the relative rate of Jearning in collaboration versus hietarchy. We did not include prior relationships in out formal presentation because to the exient that culural dimensions influence the choice of prior relationships with the partmer, including a measure of prior transactions in the model would confound our ability to interpret the resuits. In nuns not reported, we did, include a dummy measure for prior telationships, consistent with the measure employed by Park and Ungson, but found no significant relationship in any of our models. Surprisingly, only 7.0 percent of the partnerships had a prior relationship, a number significantly below Park and Ungson's 26.0 percent in the electronics industry. Apparently, it is more common to initiate a relationship with equity mansections in the biotechnology industry.

Target firms having more commercial partners may not be attractive buyout candidates because commercial opportunities to exploir their technology may be siphoned off by others. To approximate the declining marginal threat of preemptive bidding or acquisition by each additional partner, we used the natural loganithm of the target firm's number of current commercial alliances. The number of partners was taken during the year of the event, in the event of right-censored cases, the measure was taken in the last year of the observation window. Bioscan provided this information. 
If the transaction was a joint venture an indicator variable was classified as a " $\mathrm{I}$ ", and " 0 " if it was a minority equity investment. Joint ventures are thought to provide a real option that is more proprietary than is the case for minority investments.

Insert Table 2 about here

\section{Restuts}

Table 2 provides descriptive statistics and correlations for the variables. Because of concerns of inulticolinearity between Uncernainty Avoidance and the Cultural Distance variahles, as well as the small number of events, we opted to present three full models relating to our hypotheses.

Table 3 presents the fuil (columns $2,4,6$ ) and reduced (columns 1,3,5) models with the parameter estimates for the hazard of partner buyout. To ascertain the degree of model fit. likelihood ratio tests were performed on the incremental and full models. Each test produced a chi-square statistic well above the critical value $(\mathrm{p}<0.001)$, indicating that the overall fit is good. The hypotheses for the individual interacties coefficients are tested under one-tail $\mathrm{t}$-tests. In each of the full models, the hypothesized interaction is positive and significant. These findings are consistent with our expectations

Insert Table 3 about here

In model 2 , the positive coefficient on the interaction $(\mathrm{p}<0.05$ ) between Uncentainty Avoidance and Power Distance is consistent with the expectations offered is bypothesis 1. It suggests that established firms from cultures higher in UA and PD should be more likely to buy out their partners. 
In model 54 and 6 , both the positive coefficient on the interaction $(\mathrm{p}<0,10)$ between Hofstede's Cultural Distance and Power Distance as well as the posituve coefricient on the interaction $(\mathrm{p}<0.01)$ between Ronen's Cultural Distance and Power Distance are consistent with the expectations offered in hypothesis 2 . It suggests that when partners that are more cuiturally. distant and establistied investors are higher in Power Distance there is an increased likelihood of partner buyout.

Since the remaining variables in the models have no hypotheses related to them, we use a two-tailed rest to assess the significance of refationships. The onily variable that demonstrated a significant effect was Target Firm's Number of Partners. As was expected, it was negatively related to the likelitiood of partner buyout. This vartable should approximate how proprietary the buyout option is. The more partners a turgel partner has, the less proprietary is the oprion. The variables relating to exogenous uncertainty, subfieJd vaiue, and subfield R\&D expense were not significant Neither was the indicator variable distinguishing joint ventures from minority investments:

Tuble 3 also includes the competing hazard results for partnership dissolution in columns 7 10. These resuits indicate that Uncertainty Avoidance and Ronen's Cultural Distance is negatively related to the likelihood of dissolution. The latter result is consistent with those found by Park and Ungson (1997) in studying the electronics industry. They did not examine the effect of Uncertainty A voidance. Furthermore, in eomparison with the findings for the partner acquisition models, these findings demonstrate that national culture atuributes influence partner dissolution differently, ${ }^{10}$

Consistent with previous studies, we focused mainly on aggregate measures of euhtural distance. However, Hofstede (1980) suggests that partner differences for power distance. 


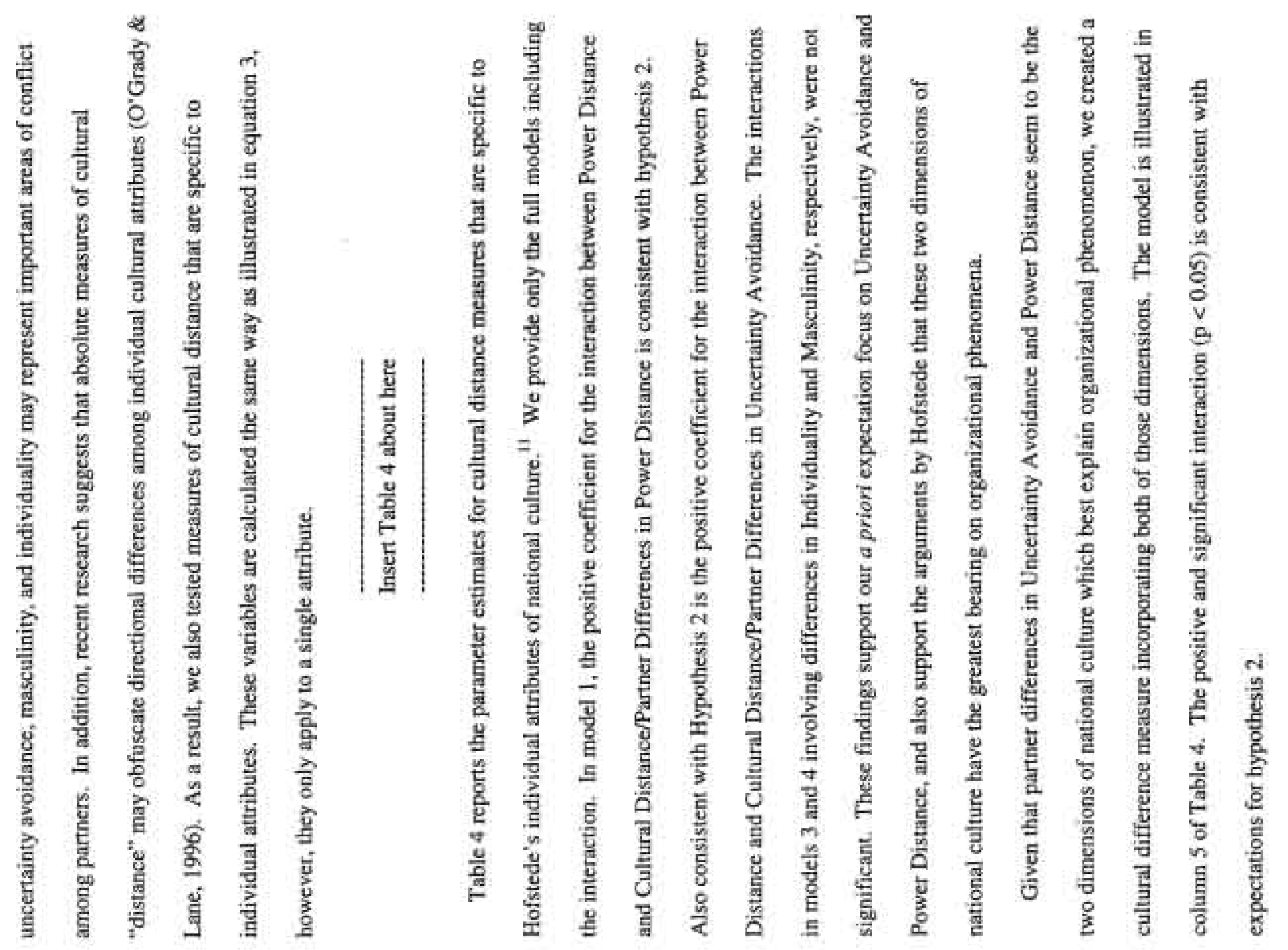




\section{Discussion}

The role of national culnue on governance choice has been frequently studied, However, these studies have fargely focused on the initial governance decision or partnership termination, giving little attention specifically to parnet buyouts. This oversight is consequential, given the high incidence of acquisition of joint venture and equity partters. By explicitiy considering the mole of national culture on parner buyouts, we extend a growing body of literature that examines the incremental nature of investments in joint ventures and partner firms in knowledge-intensive industries. Although we are the not the first to characterize equity collaborations are compound options, our study is the first to attempt to theoretically explain the role of national culture on partner buyout. Partmer buyoul represents the exercise of the first stage option, while funte discretionary investments represent the exercise of the second stage option. Real option theory. suggests that firms should choose to inyest incrementally in the face of endogenous uncertainty. It aiso suggests that firms will be more likely to commit to the next stage when they can learn more by committing, thereby reducing endogenous uncertainty.

We have built upon option theory to suggest that partner buyouts will be influenced by three factors: exogenous variables, endogenous uncertainty, and the rate of learning inside versus outside the fim: Our central argument is that attributes of national culture bears upon these latter two factors. Specifically, we argue that both uncertainty avoidance and cultural distance increases endogenous uncerainty. This is Tikely due to the inability to percejve the potential for: opportunistic behavior by partners, or information asymmetry between partners. As a result of such uncertainty, established firms will shy away from aggressive cormmitment to growth opportunities, they will invest incrementally. Firms from cultures that are high in power distance are expected to transition to hierarchical governance because it is in hierarchies that they operate 
and learn most efficiently about growth opportunities. Thus, it is the combination of high endogenous uncertainty and the abjility (or prospects) to learm more efficiently after internalizing the partner that leads to partner buyout.

Our empirical findings are consistent with the expectations noted above. Uncertainty avoidance and cultural distance are argued to contribute to endogenous uncertainty, while power distanee is argued to impact the relative rate of learning in hierarchy relative to eollaborations. Established firms from high UA home country cultures are more likely to buy out partners when they are also high in PD. Parners that are culturally tistarit are more likely to buy out partners when they are also high in PD. These findings suggess that it is the combination of endogenous uncertainty and efficient learning at the next stage that promote commitment via partner buyout. They are robust to different measures of cultural distance emanating from work by Hof stede (1980) and Ronen and Shenkar (1985). Distance measures using Hofstede's dimensions of Uncertainty Avoidance and Power Distance seem to mostly explain endogenous uncertainty. Upon examination of country values for UA. Japan is ameng the world's most uncertainty avoidant cultures (abour 1.5 standard deviations above the mean; see Hof'stede, 1980; 315 ). According to our research findings, lapanese firms might be expected to exhibit high levels of anxiety with respect to both endogenous uncertanty and exogenoss uncertainty Therefore, Japanese firms will place greater intrinsic and extrinsic value on maintaining the equity collaboration. Indeed, our findings suggest that firms high in UA (including those from lapan) are less likely to acquire their collaboration partners and less tikely to dissolve the parthership. These findings suppon those of Hurry er al. (1992) and Chang (1995) who found that Japanese firms were more likely than U.S. firms to retain their holdings in international foint ventures. 


\section{A Framework for Understanding Intentions of Foreign Partners}

Using Hofstede's dimensions of Uncertainty Avoidance and Power Distance there is potential to create a broad framework by which future studies can examine partner buyout decisions in particular, and sequential investment more generally. In Table 5 we located countries based on only two measures: Uncertainty A voidance and Power Distance. Since these measures are specific to the established firm, and not the relationship between partners, we can develop a genetal framework of tendencies toward partuer buyout. Since firms domiciled in France and Japan are high in both Uncertainty Avoidance and Power Distance, we expect thern to be most tikely to buy out their partners. The second most likely group to buy out partners. consists of firms high in Uncertainty Avoidance asd medium in Power Distance: Germany, Italy, and Switzerland. Finally, firms from countries that are medium in both PD and UA (Australia, Canada, the United Kingdom, or the United States) max also demonstrate a notion for partner buyouts, although to a lesser extent. Established fitms from other countries are less likely to exhibit a tendency to buy out their parners either because there is low power distance or low uncertainty avoidance.

Insent Table 5 about here

Of course, ctitural distance is not depicted in Table 5. According to our theoretical expectations, eveu established firms from uncertainty avoidance cultures may display a tendency to buy out partners if they are cuiturally distant. The expectations presented in Table 5 can be altered to reflect zultural distance. For example, France and Japan are especially likely candidates for buyouts of U.S. parmers because they are high on all three cultural attributes: Power Distance, Uncertainty Avoidance, and Cultural Distance. The framework can be extended 
to partnerships not involving United States target firms. For example, the tendency for Japanese firms to acquire Japanese partners may be muted somewhat because of a lack of culturai distance. At the same time, because of high cultural distance, firms from Australin, Canada, the United Kingdom, and the United States may demonstrate an increased tendency for acquiring Japanese partners. We believe that these propositions are very deserving of thone attention in samples. involving multiple industries and entry into moltiple countres.

We should note several limitations of this study. Although our sampling methodology was comprehensive for nearly the entire life of the biotechnology industry, the number of partner buyout events is smaft. Nevertheless; we managed to attain statistical significance for our key variables and stability across a number of modeis containing firm-level and/or industry-level control variables. A larger sample would allow disaggregation of joint ventures and minority. equity pannerships. Oar study focused on a single industry, and sub-segments within that industry. While these segments are distinct from one another, future research should attempt to verify the expected relationships in other industries, inciuding both $R \& D$ intensive and more stable industries.

Parkbe (1991) suggests that formal training programs can entance cultural understanding and may moderate the relationship between cultural yariables and the duration of global allances. These integrating mechanisms may have an important influence on the relative ratc of learning in joint ventures versus acquisition, and hence, thay play a role in the buyout decision. Unfortunately; since we lacked data on the extent of cross-cultural training programs, we could not examine this issoe, However, we believe that our theoretical framework offers an interesting new opportunity to ascertain how integrating mechanisms may influence the relatively unexplered phenomena of partner buyouts. 
Previous research has demonstrated that companies use collaburations when partnering with culturally distant partners. Thus, our sample of equity collaborations may reffect some restricted range of eultural distance. Indeed, means scores of cultural distance varied significantly when we. examined a broader sample of transactions involving both equity collabarations $(0.64)$ and outright acquisitions (.036). Thus, our study, and any stady examining the effect of national culture on partner buyout will suffer from such a bias. This will tend to weaken the results for cultural distance. We have demonstrated, however, that even though we have sampled culturally distant parneers, power distance acts to moderate the partner buyout decision.

Overall, our study suggests that cultural attributes of the investing firm and cultural differences between the investing and target firms play a significant role in predicting the rate at which parner buyouts occur, It suggests that firms find value in flexibility in the presence of endogenous uncertainty, and are quicker to exercise wher buyout entunces the potential rate of learning. The hypotheses developed here and the resulis we found offer some promising new directions for futire empirical research. 


\section{ENDNOTES}

' Oiber evidence of parner buyouts include Kogut (1989), who found that 24.0 percent of joint ventures were acquired by a partner within seven years, and Mikkelson and Ruback (1985), who discovered that 13.6 percent of firms having inituated minority investments either acquired or attempted to acquire their partner within three years of taking an initial equity stake.

2 We are not without precedent in defining the scope of this research to encompass both joint ventures and minorify investments (c.g. Hennart, 1991; Pisano, 1989).

${ }^{3}$ For Williamson (1985), the ownership atvaniage of the firm results from its superior mechanisms for coping with opportunism.

${ }^{4}$ Although Hofstede is largely famous for his 1980 IBM national culture study, he and his colieagues later found several links berween national culture and organizational culture (Hofstede, 1991; Hofstede, Neuijen, Ohayv, \& Sanders, 1990). In particular, the organizational culture dimensions of need for authority and need for security conrelated strongly with power distance and uncertainty avoidance, respectively. Therefore, we restrict our analysis to only power distance and uncertainty avoidance - cultural dimensions that capture both nitional and organizational traits.

${ }^{5}$ We are grateful to a reviewer who emphasized that cultural distance and uncertainty avoidance are not equated to endogenous uncertainty. Indeed, they are merely constructs that contribute to endogenous uncertainty. As pointed out on psges 6-7, endogenous uncertainty may be represented by many factors.

- Either partner may hold the option to acquire the joint venture. Who is most likely to exercise the option in the case of joint ventures turns not only on the strategic intentions of the partners, but the relative competitive strengths of the partners--the parner possessing unique complementary resources being the more likely to acquire the weaker partner's stake \{Hurry. 1993). Integrated firms investing in biotechnology have downstream skills in marketing and distribution, and regulatory savvy (Arora \& Gambardella, 1990). Although dedicated biotechrology firms (DBFs) have important R\&D capabifities, they frequently lack the cash needed to invest in acquisitions. Furthermore, most integrated manufacturers of pharmaceuticals, chernicals, and agriculture have a major goal of acquiring technical knowledge in biotechnology. while only a handful of DBF's aspire to become fully integrated (Office of Technology Assessment, 19911. In our sample we found that six joint ventures were acquired by the integrated partner and six joint ventures that were acquired by the DBF. Our focus on the established firm as the holder also rests on our theotetical interest in understanding when firms are more likely to commit to internalizing technical knowledge to capitalize on emerging technologies, and not downstream skills.

7 Although the rate of acquisition ( 6.9 percent) by year three appears somewhat below rates found in studies noted on page 3, to make our rate comparable we must also include acquisitions by the DBF partner and allow for 8 three year window for the event to take place. In making that adjustrient we find that 10.0 percent of the total sample ( 14.8 percent of joint ventures and 8.9 percent of minority investments) was terninated by acquisition by one of the partners within 36 
months. This, then, is consistent with previous studies,

The Cox method uses only information about the relative order of duration times, instead of the exact timing of events. Hence, the Cox method involves some loss of information, potentially inhibiting model estimation. This same feature makes the Cox model an attractive one when one has no prior expectations about time dependence. Another reason to question the validity of the Cox partial likelihood model for our data is that our number of events is relatively few. Although partial likelihood models are asymptotically efficient when the sample size is large (Bfron, 1977), when the sample size is small, the precision of the partial likelihood estimates can be much less than that for maximum likelihood estimates (Coleman, 1981). We estimated a second model using maximum likelihood. Maximum tikelihood methods require specification of a baseline hazand function. We chose the exponential specification because it is the parametric equivalent to the Cox method. The results from that estimation produced a pattern of relations identicail to those found via the Cox estimation, with slightly less significance. This supplemental analysis provided evidence for the robusthess of the resulis reported in this paper.

Te also examined the effect of industry structure using mumber of rivals active in each of the 123 product areas for each year throughout the publication of Bioscan (1987-1995). We did not include this yariable in the formal presentation because it had no substantive impact on the model, and there was substantial colinearity with other variables in the model (R\&D Expense and Subfield Value).

10. We atso examined whether dissolution was influenced by an interaction between cultural distance and power distance, and uncertainty avoidance and power distance. Log likelihood ratio tests indicated no such interaction existed.

II Weber, Shenkar, and Raveh (1996) also used distance measures for Hofstede's individual eulure altributes, but focused on the impact on mergers and acquisition, not partner buyouts. 


\section{REFERENCES}

Adler, N, J. 1991. Intemational dimensions of organizational behavior-Belmont, CA, Wadworth Publishing

Arora, A. \& Gamburdella, A. 1990. Complementarity and extemal linkages: The strategies of the large firms in biotechnology. The Joumal of Industrial Fconomics, 38; $361-379$.

Barkema, H. Bell, J. \& Pennings, J. 1996. Foreign entry, cultural barriers, and learning Strategic Management Joumal, 17: 151-166.

Barkema, H., Shenkar, O., Vermeulen, F. \& Bell, J. 1997. Working abroad, working with others: How firms learn to operate international joint ventures. Academy of Management Joumal, 40: $426-442$.

Chang, S.J. 199S International expansion strategy of Japanese firms: Capability bullding through sequential entry. Academy of Management Joumal, 38(2): 383-407.

Choi, D. 1991. Toehold acquisitions, shareholder wealth, and the market for corporate control. Joumal of Financial and Quantitative Analysis, 26: 391-407.

Coleman, J.5. 1981. Longitudinal data analysis. New York: Basic Books:

Cox, D.R. 1975. Partial tikelihood. Blometrika, $62: 269-76$.

Dibner M.D. 1992, U.S biotechnology and pharmaceuticals. BioPharm, 5(8): 24-28.

Dixit, A. K \& Pindyck, R. S. I994 Investment under uncertainty. Princeton, New Iersey; Princeton University Press.

Efron, B. 1977. The effuciency of Cox's likelibood function for censored data Jouma of the American Statistical Association, 72:557-65.

Elsass, P.M. \& Viega, 1.F. 1994. Acculturation in acquired organizations: A force-field perspective, Human Relations, 47:431-453.

Erramilli, K, 1996. Nationality and subsidiary ownership patterns in multinational corporations: Joumal of International Business Studies, $27: 225-248$.

Folta, T.B. 1998. Governance and Uncertainty: The tradeoff between administrative control and commitment. Straiesic Manasement foumal, 19; 1007-1028. 
Gatignon, H. \& Anderson, E 1988. The mulinational corporation's degree of control over foreign subsidiaries: An empirical test of transaction cost explanations. Journal of Law. Economics, and Organization, 4(2): $305-3,36$.

Hall, E.T. 1976. Bevond eulture. Garden City, NY: Ancbor Books/Doubleday

Harrigan, K. 1985. Strategies for joint ventures; Lexington, MA: Lexington Books:

Hennart, J.F 1991. The transaction cost theory of joint ventures. An empincal study of Japanese subsidiaries in the United States. Management Science, 37(4); 483-497.

Hoecklin, L. 1995. Managing cultural differences Strategies for competitive advantage. Rearling, MA: Addison-Wesley.

Hofstede, G. 1980. Culture's consequences: International differences in work-related vahues. Beverly Hills: Sage.

Hofstede, G. 1985. The interaction between national and organizational value systems. Joumal of Management Studies, 22: 347-357.

Hofstede, G. Neuijen, B., Ohayv, D. \& Sanders, G, 1990 . Measuring organizational cultures: A qualitative and quantitative study across twenty cases. Administrative Science Ouarterly. $35: 286-316$.

Hofstede, G, 1991, Cultures and organizations Software of the mind Berkshire, UK- McGraw. Hill

Hurry, D. 1993. Restructuring in the global economy: The consequences of strategic linkages between Japanese and U.S. firms. Strategic Management Joumal, 14:69.82.

Hurry, D., Miller, A. T. \& Bowman, E. H. 1992. Calis on high-technology: Japanese exploration of venture capital investments in the United States. Strategic Management Journal, 13: 85-101.

Kogut, B, 1988. Joint ventures: Theoretical and empirical perspectives, Strategic Managemen! Joumal, 9(4): $319-332$.

Kogut, B. 1989. The stability of joint ventures: Reciprocity and competitive fivalry. The Journal of Industrial Economics, 38: 183-198.

Kogut, B. 1991, Joint ventutes and the option to expand and acquire. Management Science, 37 : 19-33.

Kogut, B. \& Singh, H, 1988. The effect of national culture on the choice of entry mode. Lournal of International Business Studies, 49:411-430. 
Kogut, B. \& Zander, U, 1992, Knowledge of the firm, combinative capabilities and the replication of technology. Organizational Science, 3: 383-397.

Kogut, B. \& Zander, U. 1993. Knowledge of the firm and the evolutionary theory of the mulunational corporation. foumal of Intemational Business Studies; Fourth Quarter: 625645.

Luostarinen, $R$ 1980. Intermationalization of the firm. An empirical study of the internationalization of firms with small and open domestic markets with special emphasis on lateral rigidity as a hehavioral characteristic in sirgtegic decision-making Helsinki Helsinki School of Economics.

MeCardle, K. 1985. Information acquisition and the adoption of new technology. Management Science, $31(11): 1372-1389$.

McDonald, R. \& Siegel, D. 1986. The value of waiting to invest. Quanterly Journal of Economies, $101: 707-28$.

Mikkelson, W. H. \& Ruback, R. S. 1985. An empirical analysis of the interfirm equity investment process. Jommal of Finahcial Esonomics, 14: 523-553.

Mintzberg. H. 1983, Structire in fixes: Designing effective organizations. Englewood Cliffs, NJ: Prentice Hall.

O'Grady, S. \& Lane, H. 1996. The psychic distance paradox. Loumal of Intemational Business Studies, 27; 309-334.

Office of Technology Assessment. 1991. Biotechnologr in a global economy. Congress of the United States, Washington, D.C.

Ofie, R. 1994, Shades of culture and institutions in international mergers. Organizational Studies, 15: $381-405$.

Osborn, R. \& Hagedoom, J.1997. The institutionalization and evolutionary dymatnics of interorganizational alliances and networks. Asademy of Masagement Joumal, 40: 261-278.

Park, S \& Russo, M 1996. When competition eclipses cooperation: An event history analysis of joint venture failure. Management Science, 42: 875-890.

Park, S. \& Ungson, G. 1997. The effect of national culture, organizational complementarity, and economic motivation on joint venture dissolution, Academy of Management Journal, 40: $279-307$. 
Parkhe, A. 1991. Interfirm diversity, organizational learning, anit longevity in global strategic alliances. Journal of International Business Stodies, Fourth Quarter. 579-601.

Penner-Hahn, J, 1998. Firm and environmental influences on the mode and sequence of foreign research and development activities, Strategic Management Joumal, 19: 149-168.

Pisano, G. 1989. Using equity participation to support exchange: Evidence from the biotechnology industry, Joumal of Law, Fconomics, and Oczanization, 5(1): 109-126.

Powell, W. Koput, K, \& Sruith-Doerr, L 1996: Interorganizational collaboration and the locus of innovation: Networks of learning in biotechnology. Administrative Science Ouarterly. $41: 116-145$

Rivoli, P. \& Salorio, E. 1996. Foreign direct investment and investment under uncertainty. Journal of internationał Business Studies, 27: 335.358.

Robens, K \& Weizman, M. 1981, Funding criteria for research, development, and exploration projects. Econometrica, $49: 1261-88$.

Rohwer, G. 1994, Parametric transition rate models. TDA Working Paper 5-7, University of Bremen.

Ronen, S. \& Shenkar, O. 1985. Clustering countries on attitudinal dimensions: A review and synthesis. Academy of Management Review, 10: 434-454

Shane, S. 1993. The effect of cultural differences in the perception of transaction costs on national differences in the preference for licensing. Academy of Management Best Paper Proceedings, $122-126$

Weber, Y., Shenkar, O. \& Raveh, A. 1996. National and corporate cultural fit in mergers / acquisitions: An exploratory study. Manazement Science, 42(8): 1215-1227.

Williamson, O. E 1985. The economic institutions of capilalism. New York: Free Press. 
Table 1: Cultural Measures and Outcomes of Equity Collaborations by Country of Corporate Headquarters

\begin{tabular}{|c|c|c|c|c|c|c|c|c|c|c|}
\hline \multirow[b]{2}{*}{ Country } & \multicolumn{4}{|c|}{ Cultural Measures } & \multicolumn{6}{|c|}{$\begin{array}{c}\text { Outcomes of Equity Collaborations } \\
\text { Actual (Percent) }\end{array}$} \\
\hline & UA & PD & $\begin{array}{l}\text { Hofstede's } \\
\text { Cult. } \\
\text { Distance }\end{array}$ & $\begin{array}{l}\text { Ronen's } \\
\text { Cultural } \\
\text { Category }\end{array}$ & $\begin{array}{l}\text { Partner } \\
\text { Buyout }\end{array}$ & $\begin{array}{l}\text { Partnership } \\
\text { Dissolution }\end{array}$ & $\begin{array}{l}3^{\text {rd }} \text { Party } \\
\text { Buyout }\end{array}$ & $\begin{array}{l}\text { Partnerships } \\
\text { Maintained }\end{array}$ & Total & $\begin{array}{c}\text { \# of } \\
\text { Establish } \\
\text {-ed Firms }\end{array}$ \\
\hline Australia & 51 & 36 & 0.026 & Anglo & $1(100 \%)$ & $0(0 \%)$ & $0(0 \%)$ & $\theta(0 \%)$ & 1 & 1 \\
\hline Canada & 48 & 39 & 0.138 & Anglo & $\theta(0 \%)$ & $\mathrm{I}(50 \%$ & $1(50 \%)$ & $0(0 \%)$ & 2 & I \\
\hline Denmark & 23 & 18 & 1.745 & Nordic & $1(50 \%)$ & $I(50 \%)$ & $0(0 \%)$ & $0(0 \%)$ & 2 & 2 \\
\hline France & 86 & 68 & 1.617 & Latin Europe & $2(40 \%)$ & $0(0 \%)$ & $0\langle 0 \%)$ & $3(60 \%)$ & 5 & 2 \\
\hline Germany & 65 & 35 & 0.630 & Germanic & $0(0 \%)$ & $0(0 \%)$ & $2(28.6 \%)$ & $5(71.4 \%)$ & 7 & 2 \\
\hline Ireland & 35 & 28 & 0.530 & Anglo & $1(50 \%)$ & $1(50 \%)$ & $0(0 \%)$ & $0(0 \%)$ & 2 & I \\
\hline Italy & 75 & 50 & 0.650 & Latin Europe & $1(50.0 \%)$ & $0(0 \%)$ & $0(0 \%)$ & $\mathrm{I}(50.0 \%)$ & 2 & 2 \\
\hline Japan & 92 & 54 & 3.104 & Far East & $3(13.6 \%)$ & $3(13.6 \%)$ & $1(4.6 \%)$ & $15(68.2 \%)$ & 22 & 17 \\
\hline Norway & 50 & 31 & 1.667 & Nordic & $0(0 \%)$ & $1(100 \%)$ & $0(0 \%)$ & $0(0 \%)$ & 1 & 1 \\
\hline Sweden & 29 & 31 & 1.859 & Nordic & $1(12.5 \%)$ & $2(25.0 \%)$ & $1(12.5 \%)$ & $4(50.0 \%)$ & 8 & 4 \\
\hline Switzeriand & 58 & 34 & 0.528 & Germanic & $3(17.7 \%)$ & $1(5.8 \%)$ & $3(17.2 \%)$ & $10(58.8 \%)$ & 17 & 3 \\
\hline United Kingdom & 35 & 35 & 0.083 & Anglo & $0(0 \%)$ & $1(7.1 \%)$ & $0(0 \%)$ & $13(92.9 \%)$ & 14 & 3 \\
\hline United States & 46 & 40 & 0.000 & Anglo & $10(11.1 \%)$ & $28(31.1 \%)$ & $13(14.5 \%)$ & $39(43.3 \%)$ & 90 & 34 \\
\hline Total & & & & & $23(13 \%)$ & $39(23 \%)$ & $21(12 \%)$ & $90(52 \%)$ & 173 & 73 \\
\hline
\end{tabular}


Table 2: Descriptive Statistics and Correlation Matrix

\begin{tabular}{|c|c|c|c|c|c|c|c|c|c|c|c|c|c|c|}
\hline & & Mean & S.D & 1 & 2 & 3 & 4 & 5 & 6 & 7 & 8 & 9 & 10 & 11 \\
\hline 1. & Uncertainty Avoidance & 53.143 & 18.157 & & & & & & & & & & & \\
\hline 2. & Hofstede's Culturnal Distance & 0.632 & 1.078 & $0.786 \cdot$ & & & & & & & & & & \\
\hline 3. & Ronen's Cultural Distance & 0.343 & 0.475 & $0.653 *$ & $0,795 *$ & & & & & & & & & \\
\hline 4. & Power Distance & 40.804 & 8.141 & $0.823 *$ & $0.572 *$ & $0.268 *$ & & & & & & & & \\
\hline 5. & $\mathrm{UA} \cdot \mathrm{PD}$ & 2290.158 & 1283.659 & $0.964 *$ & $0.794 *$ & $0.573 *$ & $0.918 *$ & & & & & & & \\
\hline 6. & Hofstede's CD * PD & 30.817 & 57.567 & $0.869 *$ & $0.977^{*}$ & $0.728^{*}$ & $0.711^{*}$ & $0.893 \bullet$ & & & & & & \\
\hline 7. & Ronen's CD * PD & 15.023 & 22.129 & $0.835 *$ & $0.879 *$ & $0.940 *$ & $0.568 *$ & $0.807 *$ & $0.876 *$ & & & & & \\
\hline 8. & Exogenous Uncertainty & 0.3191 & 0.103 & $-0.035 *$ & -0.006 & -0.004 & $-0.027 \cdot$ & $-0.029 \bullet$ & -0.014 & -0.013 & & & & \\
\hline 9. & Subfield Value & 5.736 & 1.095 & $0.050^{*}$ & $0.050^{*}$ & $0.099+$ & $0.026 *$ & $0.052 \cdot$ & $0.056 *$ & $0.106+$ & $0.098^{*}$ & & & \\
\hline 10. & Subfield R\&D Expense & 41.423 & 11.846 & $0.135 *$ & $0.188+$ & $0.201 *$ & $0.052 *$ & $0.1333^{*}$ & $0.186 *$ & $0.205^{+}$ & $0.107 \bullet$ & $0.328 *$ & & \\
\hline 11. & Target's \# of Partners & 3.118 & 1.625 & $-0.030^{+}$ & $-0.177 \cdot$ & $-0.040 *$ & $-0.128 \cdot$ & $-0,112 *$ & $-0.173 *$ & $-0.086 *$ & -0.003 & -0.021 & $-0.076^{*}$ & \\
\hline 12 & Joint Venture & 0.170 & 0.375 & $0.067 *$ & $0.035^{*}$ & $0.072 *$ & $0.053 *$ & $0.058 *$ & $0.039 *$ & $0.073 *$ & $-0.035 *$ & $-0.109 *$ & $-0.084 *$ & $0.164 *$ \\
\hline
\end{tabular}

* Pearson correlations are significant at $\mathrm{p}<0.05$.

- Correlations are calculated using pooled cross-sectional and time-series data covering 173 equity partnerships and 9,843 one-month periods. 
Table 3: Partial Likelihood Estimates for Hazard of Partner Buyout and Partnership Dissolution

\begin{tabular}{|c|c|c|c|c|c|c|c|c|c|c|}
\hline \multirow[b]{2}{*}{ Variable Name } & \multicolumn{6}{|c|}{ Partnership Acquisition } & \multicolumn{4}{|c|}{ Partnership Dissolution } \\
\hline & (1) & (2) & (3) & (4) & (5) & (6) & (7) & (8) & (9) & (0) \\
\hline Uncertainty Avoidance & $\begin{array}{l}-0.0278 \\
(0.0197)^{\circ}\end{array}$ & $\begin{array}{l}-0.0338 \\
(0.0356)\end{array}$ & & & & & $\begin{array}{l}-0.0179 \dagger \\
(0.0102)\end{array}$ & & & \\
\hline Hofstede's Cultural Distance & & & $\begin{array}{c}0.1899 \\
(0.2100)\end{array}$ & $\begin{array}{l}-0.7904 \\
(0.6699)\end{array}$ & & & & $\begin{array}{l}-0.2919 \\
(0.1823)\end{array}$ & & \\
\hline Ronen's Cultural Distance & & & & & $\begin{array}{c}0.6992 \\
(0.4355)\end{array}$ & $\begin{array}{l}-2.7992 * \\
(1.5773)\end{array}$ & & & $\begin{array}{l}-0.8394 * \\
(0.4066)\end{array}$ & \\
\hline Power Distance & $\begin{array}{l}-0.0660 \\
(0.0420)\end{array}$ & $\begin{array}{l}-0.0996^{*} \\
(0.0392)\end{array}$ & $\begin{array}{l}-0.0262 \\
(0.0246)\end{array}$ & $\begin{array}{l}-0.0510^{*} \\
(0.0254)\end{array}$ & $\begin{array}{l}-0.0215 \\
(0.0210)\end{array}$ & $\begin{array}{l}-0.0902 * * \\
(0.0306)\end{array}$ & & & & $\begin{array}{r}-0.0315 \\
(0.0195 \\
\end{array}$ \\
\hline $\mathrm{UA} * \mathrm{PD}$ & & $\begin{array}{l}0.0012^{*} \\
(0.0006)\end{array}$ & ${ }^{4}$ & & & & & & & \\
\hline Hofstede's CD * PD & & & & $\begin{array}{l}0.0219 t \bullet \\
(0.0136)\end{array}$ & & & & & & \\
\hline Ronen's CD * PD & & & & & & $\begin{array}{c}0.0903 * * \bullet \\
(0.0388)\end{array}$ & & & & \\
\hline Exogenous Uncertainty & $\begin{array}{l}-2.0209 \\
(2.2834)\end{array}$ & $\begin{array}{l}-1.8379 \\
(2.2631)\end{array}$ & $\begin{array}{l}-2.3513 \\
(2.2945)\end{array}$ & $\begin{array}{l}-1.8959 \\
(2.3054)\end{array}$ & $\begin{array}{l}-2.3481 \\
(2.2896)\end{array}$ & $\begin{array}{l}-1.8051 \\
(2.2970)\end{array}$ & $\begin{array}{r}2.6796 t \\
(1.5885)\end{array}$ & $\begin{array}{c}3.1736 \\
(1,6273)\end{array}$ & $\begin{array}{l}3.2658^{*} \\
(1.6409)\end{array}$ & $\begin{array}{c}2.5622 \\
(1.5882)\end{array}$ \\
\hline Subfield Value & $\begin{array}{l}-0.0581 \\
(0.1951)\end{array}$ & $\begin{array}{l}-0.0775 \\
(0.2020)\end{array}$ & $\begin{array}{l}-0.0612 \\
(0.1962)\end{array}$ & $\begin{array}{l}-0.0666) \\
(0.1976)\end{array}$ & $\begin{array}{l}-0.0736 \\
(0.1954)\end{array}$ & $\begin{array}{l}-0.1045 \\
(0.1988)\end{array}$ & $\begin{array}{l}0.1934 \\
(0.1637)\end{array}$ & $\begin{array}{l}0.2007 \\
(0.1631)\end{array}$ & $\begin{array}{c}0.2183 \\
(0.1638)\end{array}$ & $\begin{array}{c}0.2045 \\
(0.1634)\end{array}$ \\
\hline Subfield R\&D Expense & $\begin{array}{l}-0.0131 \\
(0.0165)\end{array}$ & $\begin{array}{l}-0.0217 \\
(0.0174)\end{array}$ & $\begin{array}{l}-0.0143 \\
(0.0170)\end{array}$ & $\begin{array}{l}-0.0175 \\
(0.0172)\end{array}$ & $\begin{array}{l}-0.0154 \\
(0.0168)\end{array}$ & $\begin{array}{l}-0.0220 \\
(0.0174)\end{array}$ & $\begin{array}{c}0.0148 \\
(0.0164)\end{array}$ & $\begin{array}{c}0.0140 \\
(0.0162)\end{array}$ & $\begin{array}{c}0.0151 \\
(0.0164)\end{array}$ & $\begin{array}{c}0.0124 \\
(0.0162)\end{array}$ \\
\hline Target Firm's \# of Partners & $\begin{array}{l}-0.4819^{* *} \\
(0.1627)\end{array}$ & $\begin{array}{l}-0.3797^{\circ} \\
(0.1678)\end{array}$ & $\begin{array}{l}-0.4524 * * \\
(0.1659)\end{array}$ & $\begin{array}{l}-0.4213 * * \\
(0.1632)\end{array}$ & $\begin{array}{l}-0.4567 * \bullet \\
(0.1637)\end{array}$ & $\begin{array}{l}-0.3884^{*} \\
(0.1622)\end{array}$ & $\begin{array}{l}-0.4584 * * * \\
(0.1291)\end{array}$ & $\begin{array}{l}-0.4982^{* * *} \\
(0.1303)\end{array}$ & $\begin{array}{l}-0.4851^{* * *} \\
(0.1310)\end{array}$ & $\begin{array}{l}-0.4775 * * * \\
(0.1289)\end{array}$ \\
\hline Joint Venture & $\begin{array}{c}0.6862 \\
(0.5065)\end{array}$ & $\begin{array}{c}0.6543 \\
(0.5057) \\
\end{array}$ & $\begin{array}{c}0.6032 \\
(0.5020)\end{array}$ & $\begin{array}{c}0.6359 \\
(0.5008) \\
\end{array}$ & $\begin{array}{c}0.6449 \\
(0.4986) \\
\end{array}$ & $\begin{array}{c}0.6671 \\
(0.4954)\end{array}$ & $\begin{array}{c}0.1343 \\
(0.4955) \\
\end{array}$ & $\begin{array}{c}0.0792 \\
(0.4911)\end{array}$ & $\begin{array}{c}0.0966 \\
(0.4917) \\
\end{array}$ & $\begin{array}{c}0.1550 \\
(0.4976)\end{array}$ \\
\hline Log-likelihood Ratio & $-326.70 * \cdots$ & $-324.72=2 * 4$ & $-326.98^{* * *}$ & $-325.86^{* * *}$ & $-325.14^{* * *}$ & $-322.93 * * *$ & $327.52 * * *$ & $328.21 * *$ & $327.20 * * *$ & $328.52 * 44$ \\
\hline
\end{tabular}

- Standard error in parentheses

$\dagger p<0.10 ; * p<0.05 ;{ }^{* *} p<0.01 ; * * * p<0.001$

- One-tailed t-test for hypothesized relations 
Table 4: Partial Likellhood Estimates for Hazard of Partner Buyout

\begin{tabular}{|c|c|c|c|c|c|}
\hline Variable Name & (1) & (2) & (3) & (4) & (5) \\
\hline $\begin{array}{l}\text { Cultural Distance - Partner } \\
\text { Differences in PD }\end{array}$ & $\begin{array}{l}0.4271 \\
(0.6234)^{*}\end{array}$ & & & & \\
\hline $\begin{array}{l}\text { Cultural Distance - Partinet } \\
\text { Differences in UA }\end{array}$ & & $\begin{array}{l}-1.3022 \\
(0.7499)\end{array}$ & & & \\
\hline $\begin{array}{l}\text { Cultural Distance - Parmer } \\
\text { Differences in Individuality }\end{array}$ & & & $\begin{array}{l}-0,1099 \\
(0,8065)\end{array}$ & & \\
\hline $\begin{array}{l}\text { Cuitural Distance-Partner } \\
\text { Differences in Masculinity }\end{array}$ & & & & $\begin{array}{l}-0.5841 \\
(0.5007)\end{array}$ & \\
\hline $\begin{array}{l}\text { Cultural Distance - Partner } \\
\text { Differences in }(P D+U A)\end{array}$ & & & & & $\begin{array}{l}0.4084 \\
(0.3592)\end{array}$ \\
\hline Power Distance & $\begin{array}{l}0.0594 \\
(0.0251)\end{array}$ & $\begin{array}{l}0.0531 \cdot \\
(0.0252)\end{array}$ & $\begin{array}{l}0.0323 \\
(0.0305)\end{array}$ & $\begin{array}{l}0.0404 \\
(0.0263)\end{array}$ & $\begin{array}{l}-0.0647 \\
(0.0269)\end{array}$ \\
\hline Differences in $\mathrm{PD} \cdot \mathrm{PD}$ & $\begin{array}{l}0.0201^{*} \\
(0.0116)\end{array}$ & & & & \\
\hline Differences in UA * PD & & $\begin{array}{l}0.0295 * \bullet \\
(0.0137)\end{array}$ & & & \\
\hline Differences in Individatity $+\mathrm{FD}$ & & & $\frac{0.0042 *}{(0.0157)}$ & & \\
\hline Differences in Masculinity * PD & & & & $\begin{array}{l}0.01834 \\
(0.0145)\end{array}$ & \\
\hline Differences in $(\mathrm{PD}+\mathrm{UA}) * \mathrm{PD}$ & & & & & $\begin{array}{l}0.0127 * * \\
(0.0064)\end{array}$ \\
\hline Exogenous thcertainty & $\begin{array}{l}-1.9168 \\
(2.2621)\end{array}$ & $\begin{array}{l}-1.6697 \\
(2.2915)\end{array}$ & $\begin{array}{l}-2.2012 \\
(2.2884)\end{array}$ & $\begin{array}{l}-2.0129 \\
(2.3173)\end{array}$ & $\begin{array}{l}-1.7917 \\
(2.2811)\end{array}$ \\
\hline Subfield Value & $\begin{array}{l}0.1443 \\
(0.2066)\end{array}$ & $\begin{array}{l}0.0984 \\
(0.2014)\end{array}$ & $\begin{array}{l}0.0560 \\
(0.1964)\end{array}$ & $\begin{array}{l}-0.0664) \\
(0.1960)\end{array}$ & $\begin{array}{l}0.1110 \\
(0.2019)\end{array}$ \\
\hline Subfield R\&D Fixpense & $\begin{array}{l}-0.0195 \\
(0.0173)\end{array}$ & $\begin{array}{l}-0.02514 \\
(0.0124)\end{array}$ & $\begin{array}{l}-0.0140 \\
(0.0169)\end{array}$ & $\begin{array}{l}-0.0143 \\
(0.0170)\end{array}$ & $\begin{array}{l}-0.0212 \\
(0.0175)\end{array}$ \\
\hline Target Firm's N of Partners & $\begin{array}{l}0.3839^{\circ} \\
(0.1659)\end{array}$ & $\begin{array}{l}-0,3882 \\
(0.1635)\end{array}$ & $\begin{array}{l}-0,4597 * * \\
(0.1659)\end{array}$ & $\begin{array}{l}-0.4460 * * \\
(0.1641)\end{array}$ & $\begin{array}{l}0.3734 \\
(0.1652)\end{array}$ \\
\hline Joint Venture & $\begin{array}{c}0.5012 \\
(0.5013) \\
\end{array}$ & $\begin{array}{c}0.5850 \\
(0.5028) \\
\end{array}$ & $\begin{array}{c}0.6206 \\
(0.5059)\end{array}$ & $\begin{array}{r}0.6045 \\
(0.5009)\end{array}$ & $\begin{array}{c}0.5825 \\
(0.4993) \\
\end{array}$ \\
\hline Log-fikelihood Ratio & $-32394 * * *$ & $-324.71 * *$ & $-327,43 * * 4$ & $-326.88 \cdots \cdots$ & $-324.14 * * *$ \\
\hline
\end{tabular}

7. Standard ertor in parentlieses

I $\mathrm{p}<0.10 ; * \mathrm{p}<0.05 ; * * 0<0.01$ * $^{* 2 * *} \mathrm{p}<0.001$

- One-tailed 1-lest for hypothesized relations. 
Table 5: Countries in Sample Located by Power Distance and Uncertainty Avoidance*

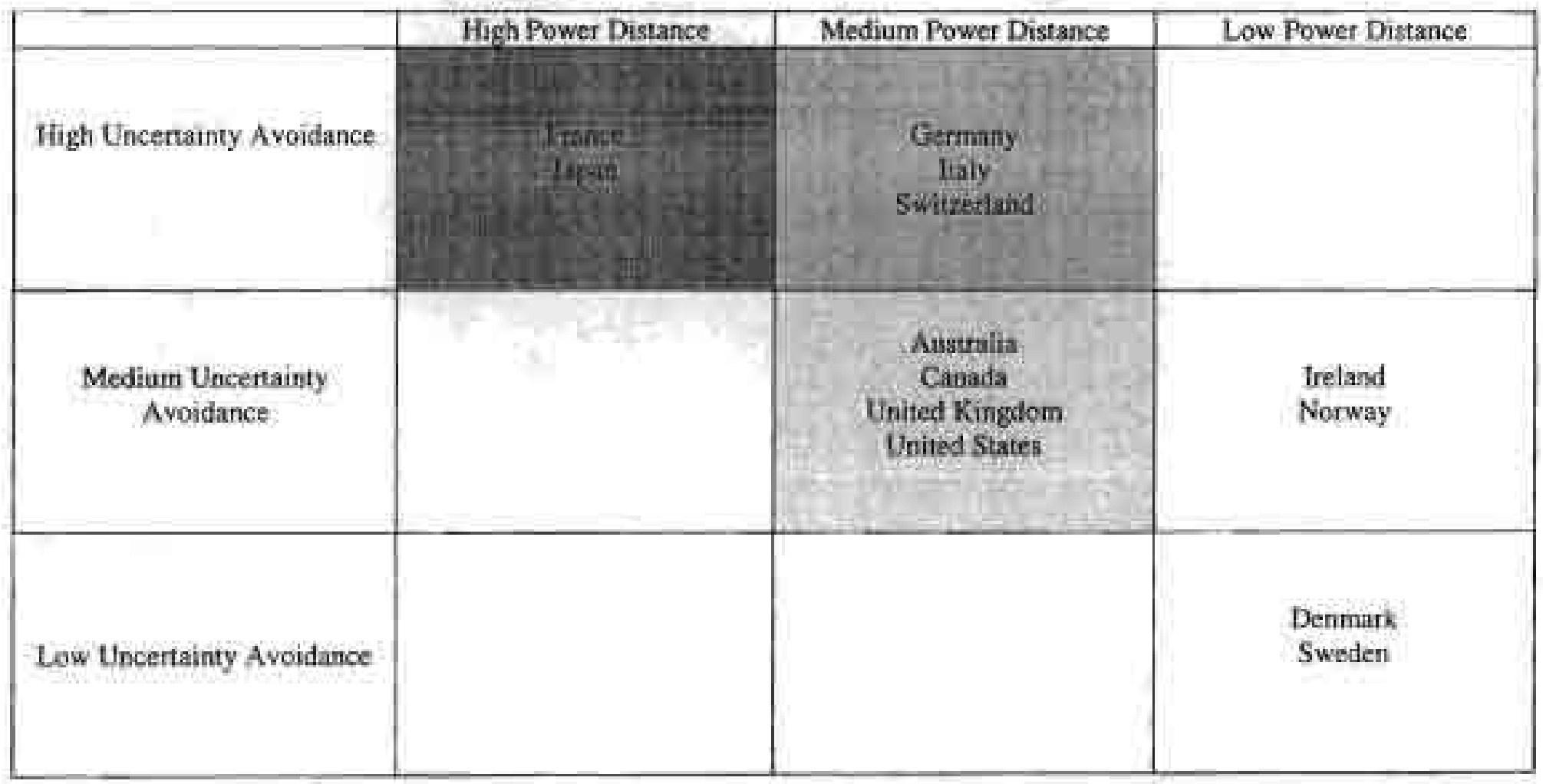

- The darker the background the inoee likely firms from these countries are to buy out their parmers. 
No: 93-101 Gordon M. Phillips, and Robert J. Weiner

"Information and Narmal Bachwardation ar Daterminants of Trading Porformancen Evidence from the North-Sea Oil Forward Market" 1994. The Economic Journal.

No. 93-102 Stephen R. Goldberg and Frank L. Hefin

"The Assorlation Refowen the Lesel of Internationat Diversification and Risk."

No. 93-163 Joln A. Cartson

"Risk Awersion, Fareign Exchange Speculatian and Gambler's Ruin."

No. 93-104 John A. Carlson, Assim M. Husain, and Jelfrey A, Zimmerman

"Penaldies and Fxcluxion in the Rescheduling and Forgiventes of Iniernational Loans."

No.93-105 Kear D. Mitter

"Industry and Country Effects on Masager's Perceptions of Enmponatental Uncertainules."

1993. Jaurnt of International Business Studies, 24: 693-714.

No. 93-106 Stephen R. Goldberg snd Joseph H. Godwin

"Foreigen Currency Translation Under Twes Cases-Imtegrated and Isolated Economies."

No. 93-107 Kent D. MUlfer

"A Comparison of Managers' timeertainty Perceptions and Country Risk Indices."

No. 93-108 Jen D. Haveman

"The Effect of Trade Induced Disptacement an Unemplayment and Wages."

Ne. 93-109 Jon D. Haveman

"Some Helfore Effects of Dynamir Castows tnion Pormation,"

No.93-410 Johis A. Cariua and Insook Kim

"Centrat Banks' Expected Prefits From Intervention."

No. 94-001 Casper G. De Vries, Phillip A. Stork, and Kees G. Koedijk

"Betwesen Redignment and Joteneation; The Belgian Frane in the European Monetary System."

No. 94-002 Casper G. de Vries and K. U. Leuven

"Stylized Factr ef Nominat Exchange Rate Returns."

No. 94-003 Kent D. Miller

"Operational Flexibility Responses to Environmental Uncertainties."

No, 94-004 Kent D. Minter

"Econamic Expesure and Iniegrated Risk Management"

Na.94-0es Kent D. Milier

"Diversification Responses to Environmentat Dincervainules."

No. 94-006 John M. Hannon, Ing-Chong Huang and Bib-Slriaw Jaw

"Internationat Human Resonrce Stratego and fis Determinanist. The Case of Muthinationals and Their Subsidiaries in Talian." 
No. 94-607 John M. Hamen, Ing-Clung Haang, and Bib-Shiaw Jaw

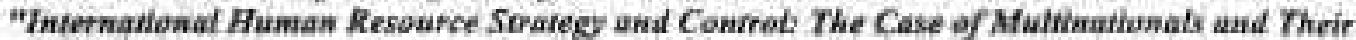
Subshiliaries."

No. 94.608 John M. Hanasa and Yoko Sane

"Cistoner-Driwn Human Resource Pollicies and Practices in Japan."

No. 94-009 John A, Carlson and Inseok Kim

"Leaning Against the Wind: Do Central Banks Necessarily Lose?"

Ne. 94-010 Joha A. Cartsen and Daviil W. Schodt

"Beyond the Lecture: Case Teaching and the Learning of Economic Throng,"

No. 94-011 Alok R. Chaturvedi, Hemant K. Jain, and Derek L. Natareth

"Key Infarmation Sywhens Management Issues in Devetoping Countries: Differences in the Indian amd us Contexss."

No. 94-412 Jon Havemun,

"The Infuence of Changing Trade Patterns an Displacements of Labor."

No. 94-013 Stephen Goldberg, Ctarles A. Tritsehler, and Joseph H. Godwin

"Financial Reporing for Foreign. Exchange Derharives."

No. 94-014 Charles Neussair, Chartes Plott, and Raymond Riezman

"Una investigacion experimantal sobre la estructura det comercia interncionel (Spanish Version)."

Traaslated: "An Ecoperimental Favestigation About the Sirnchure of Iaternationat Commerce: "

No. 94-015 Marie Thursby and Riehard Jensen

"Patent Races, Product Standards, and Internationat Competition."

No. 94-016 Kent D. Miller and Jeffrey d. Reuer

"Firm Strotegy and Ecunamic Exposure to Fordign Exchange Rate Movements."

No. 94-017 John Hanton and Yoko Sano

"The Determinants of Carporate Anroctiveness in Japaa."

No. 94-018 John Hannon, Ing-Chnag Huang, and Cheng-Chen Lin

"The Mediating Elfect of Pre/Past Assignment, Acitivitier on the Quality of Work liffe of Expatriares:

Evidence for Managers in the P.R.C."

No, 94-019 Jobn Hannon, Jug-Chung Husng, and Cheng-Cben Lin

The Mediating Effows of Organization Commianent and Job Inwotwement an the Relattonship Herween Quatlity of Worh Life and Customer Service Arnitudes."

No. 94-020 Jobin A, Cartson and Marc Surchat

"A Model far Fuller-Rule Gains in Fereign Exchange Morbess"

No. 94-021 Ch.N. Neussuir, Ch.R. Plati, and R. Riezman

"The Principles of Exchange Rate Determination in an International Finance Experiment."

No, 94-022 Stephen R, Goldherg, Joseph H. Godwis, Myung-Sun Kim, and Ctarles A. Tritsehier

"On The Deierminanis of Corporate Hedging With Fineneial Derivatives"

No. 95-001 Timothy B, Folts:

"Sovereignty Conditions and Governance Modes: An Option Theory Approach."

No. 95-002 John A. Cartson and Dong-Geun Han

"Monetary Coordination, Fixed Exchange Rates and Nolsy Markets." 
No. 95.903

Jos D. Hevenain

*Can Bamiers te Trade Male a DVJrentian"

Na. 95.and Kent D. Mitier and Jeffrey J. Deaer

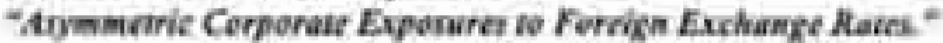

Na.95-405 Geratd J. Lyash and Bratley T. Ewing

"Mong Growth Veriabulig' end the Term Structure of Interest Nates in Japan."

Ne. \$5-406 Nicholas C. Petram and Magbeol Dada

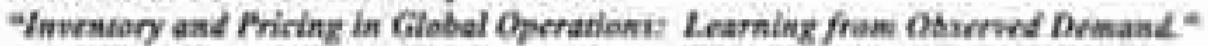

Na 95-007 Kals Krishau and Marie Thursby

"Whilher Flar Pandi Displays?"

Ne. 96-00t Thoman Brush, Caiturilae Marian, and Anset Karnani

"Manaring a Necmeck of Plante Wishin Afultinational Firms."

No. 96-002 Selan J. McCenacll, Heidl J. Dybrik, Dxvid Haushalter, and Erik Lit

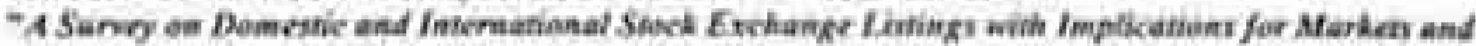
Managern:-

No. 96-003 Kaia Krishna, Suddhatatwa Roy, and Marir Thuinhy

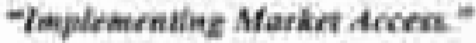

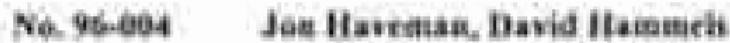

Trade Creatien and Trade Diversient Nen Empirical Rendu."

No. 96-ees Nitu Takeuchi, John M. Hannnu

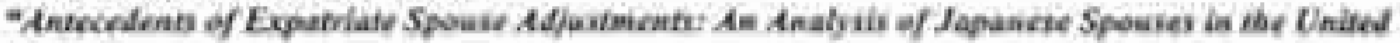
Shatre:

Na. 96-e06 Bih-5hiaw Jaw, Jahn M. Hennen

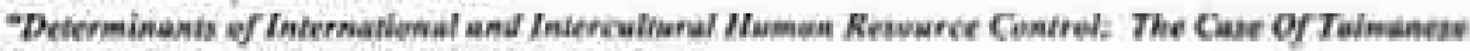

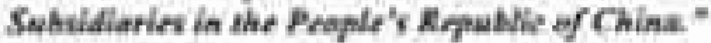

Ne. 96-00? Johe A4. Hennos, Rili Taliruehi

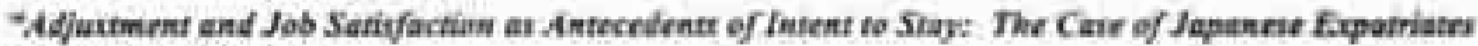
in the Hinitent Seates.

Ne. 96-abs

Johin M., Itaneon

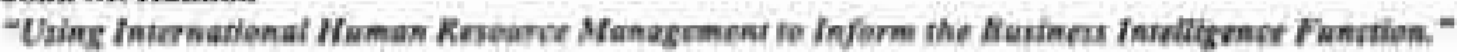

Na. 96-009 Jeflrog J. Rewer, Kent D. Milier

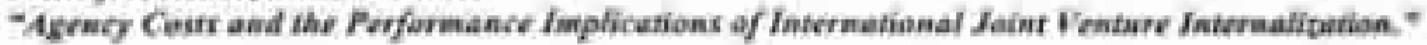

No. 96-0it Neven Vales

"Insernational Lending by US. Bandx.

Na.96-011 Kata Kristuna, Marie Thurby, and Suddhanatwa K6y

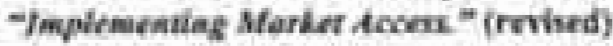

Ne.96.012 Jon D, Haveman

"The Effect of Trude Indwced Dipplacretent in Unempleqment and Wages"

No. 96.013

Rebert A. Buekle and John A. Carison

-leflatian asd Agumaneric Price Ad/ustame" 
No. S7.001 Jeffreg 2. Reuer

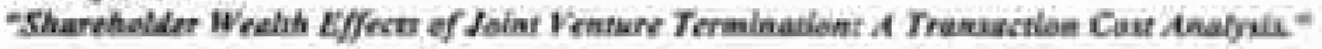

Ne.97-002 Joa Ifavrinan and Davill Humunels

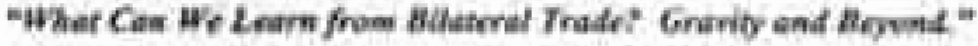

No. 97-093 Bugglas Dawask, Jotin U. Farkey, and David C. Sehmittiein

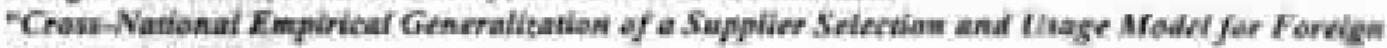

Exhesse Senten:

Ne. 97-004 Keat D. Miller

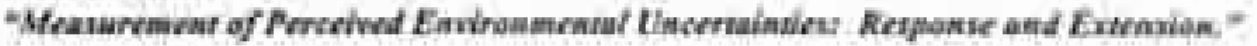

Ne.97-605 Jatua A. Carisas, C O. Onter

"Radianel Speculanors and Exihange Rate Volasilige:"

Ne. 97-005 Marle Thuraty, Kala Krblua, aind Suddhasatwa Key

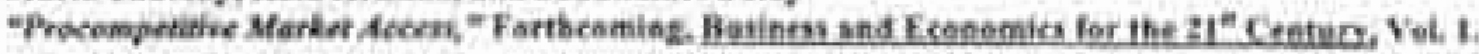

Ne. 97.007 Jalin A. Carlsea

"Carrency Boark, Expectattans and Inflativen Periluance" "

Ne. 97-008 Jos Havemall, thata C. Nair, and Jerny G. Trurnby

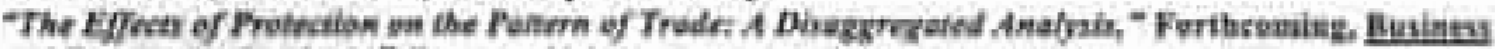
and Econemiss for the $21^{*}$ Centarn, Vot. 1.

No.97.009 George Horwich

"Econsanic Lessens of the Kobe Eerthequals"

Ne. 9l-001 Juhn J. MeConatll, Keaneth A. Carow, and Gayde R. Erwin

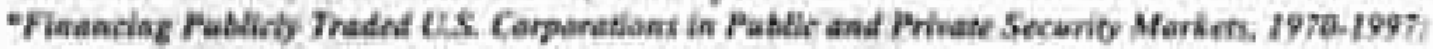

Whare, Haw, Han Afurh, With What, Whom, and Why."

No. 98-002 Timothy N. Casos, Tatsuyeshi Sajjo, and Taketiko Yamate

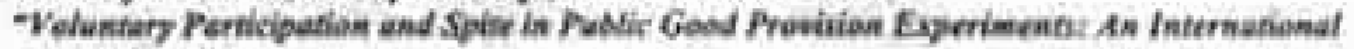

Compariaen. -

Na. 98-603 Jen D. Havenum, Janet 8. Neth, and Vivian Lei

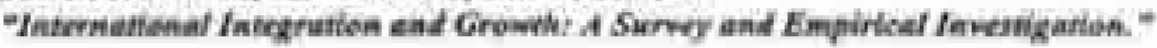

Na. 99-004 Keith V.Smith, Nabil T, Kheury, sed Peter I. MacKay

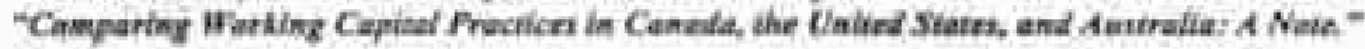

Ne. 98-005 John A. Carleon and Neres T. Valev

"Expectanians Formation and Inflation Ferianences"

Ne, 96-006 John A. Carlsan and Carel L. Oter

"Deirrminama of Carrency Rist Premiams."

Na. W5-607 Jan D. Haveman, thta Nair-Rvichert, and Jerry Thanby

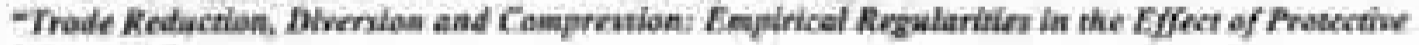
Aleasares:

Na. Qs-0es Kale Kriatex, Sedthasatwa Rey, ant Marie Thuraby

"Cau Sahsidica for MGARs be Procompvitive?"

No. 99-1901 Gabriete Camers and Johanaes Winilier

"Stores, Prices and Curreuxy Substibutios" 
No. 99-003 Thusthy N. Casen, Tatsuyoshi Saije and Takehilke Yamate

"Voluntary Participation and Spite in Pablic Good Provision Experiments: An International Compariaun"

No. 99-004 Jay Dahya, Jehn J. MeConsell and Nickolass G. Travlos

"The Cadbury Committee, Corparate Performance and Top Management Turnover"

No, 99-005. David J. Denis, Diane K. Denis and Keven Yost

"Global Diversification, Ladestriat Diversifteation and Firm Value"

Ne. 99-006 Timothy B. Folta and Wuiter $\mathcal{X}$. Ferrier

"The Effect of National Cultare on Parther Buyouts in Crass-Border Biatechnology Allinces"

No. 99-007 Jon D. Haveman and Jerry G. Tharsby

"The Iinpact of Tariff and Non-Tarif Barriens io Trade in Agricuttural Cotnmodities:

A Disaggregated Approach"

No. 99-008 Huseyts Gulen and Stewart Mayhew

"Steck Index Futures Trading and Volatifity in International Equity Markets"

No, 99-009 Stefan Lutz and Alessandro Turrini

"Skith, Labour Costs and Vertically Differcatiated ladustries: A Generse Equilibriuat Anslysis"

No.99-010 Michael Watts and Alexander Kovzik

"Reforming Ufidergraduate Economics Instruction in the Former Soviet Union" 